\title{
Uncanny Dynamism:
}

\section{Can Neuroscience inform our understanding of the Modern City?}

\author{
by \\ Marco Roberto lanni
}

A thesis submitted to the Faculty of Graduate and Postdoctoral Affairs in partial fulfillment of the requirements for the degree of

\author{
Master Degree \\ in
}

Architectural Studies

Carleton University

Ottawa, Ontario

○2012

Marco Roberto Ianni 
Library and Archives

Canada

Published Heritage

Branch

395 Wellington Street

Ottawa ON K1A ON4

Canada
Bibliothèque et

Archives Canada

Direction du

Patrimoine de l'édition

395 , rue Wellington

Ottawa ON K1A ON4

Canada
Your file Votre référence

ISBN: 978-0-494-87821-7

Our file Notre référence

ISBN: 978-0-494-87821-7

\section{NOTICE:}

The author has granted a nonexclusive license allowing Library and Archives Canada to reproduce, publish, archive, preserve, conserve, communicate to the public by telecommunication or on the Internet, loan, distrbute and sell theses worldwide, for commercial or noncommercial purposes, in microform, paper, electronic and/or any other formats.

The author retains copyright ownership and moral rights in this thesis. Neither the thesis nor substantial extracts from it may be printed or otherwise reproduced without the author's permission.
AVIS:

L'auteur a accordé une licence non exclusive permettant à la Bibliothèque et Archives Canada de reproduire, publier, archiver, sauvegarder, conserver, transmettre au public par télécommunication ou par l'Internet, prêter, distribuer et vendre des thèses partout dans le monde, à des fins commerciales ou autres, sur support microforme, papier, électronique et/ou autres formats.

L'auteur conserve la propriété du droit d'auteur et des droits moraux qui protege cette thèse. $\mathrm{Ni}$ la thèse ni des extraits substantiels de celle-ci ne doivent être imprimés ou autrement reproduits sans son autorisation.
In compliance with the Canadian Privacy Act some supporting forms may have been removed from this thesis.

While these forms may be included in the document page count, their removal does not represent any loss of content from the thesis.
Conformément à la loi canadienne sur la protection de la vie privée, quelques formulaires secondaires ont été enlevés de cette thèse.

Bien que ces formulaires aient inclus dans la pagination, il n'y aura aucun contenu manquant. 

UNCANNY DYNAMISM

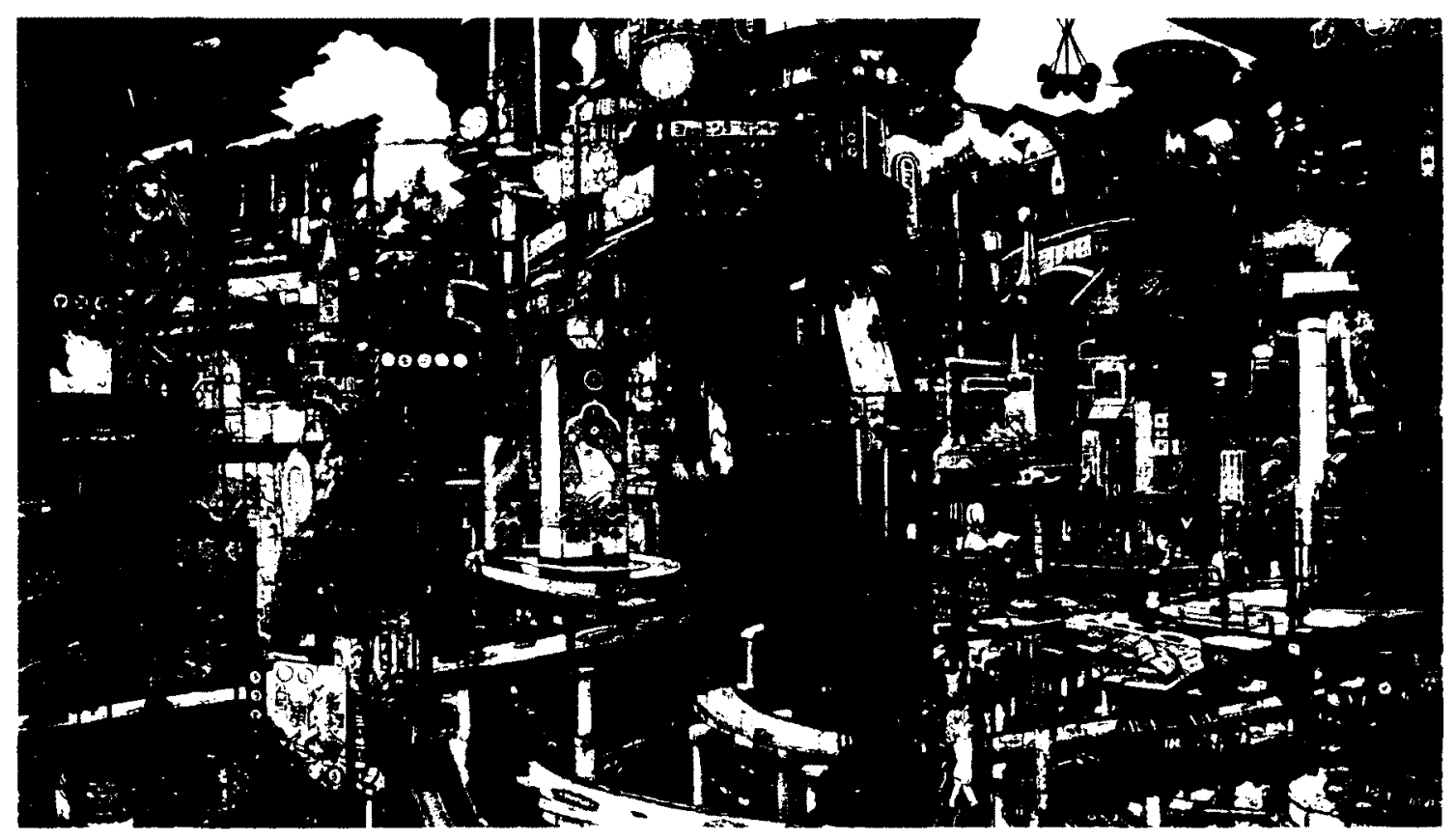

TEKKONKINKREET Manga by Taiyo Matsumoto. Shogakugan Publishers - 1994

\section{MARCO ROBERTO IANNI}

(C)

2012 


\section{ABSTRACT}

Why does the modern city feel alien? In his seminal book The Eyes of the Skin, Juhani Pallasmaa explains the feeling of alienation and detachment that one experiences in the modern city. He emphasizes that there is a lack of hapticity, or a lack of physical connection that an observer has in post-industrial cities. The media, as well as modern buildings, focus on ocularcentrism to display an immediate image or message, rather than a series of experiences which enrich and connect the user with the architecture. The scope of the thesis will be to explore the realms of neuroscience to be able to explain what this really means: what is our connection with the physical world? By asking this question, I will investigate through neuroscience how the modern city goes against perceptual needs. The influences it has on our well-being are dictated by more than biological imperatives; modern buildings pride themselves in the incorporation of green building technology and design, whether they have state of the art mechanical systems, maximization of sunlight, facilities that recycle waste matter, etc. Although admirable, these are all technical solutions. Architecture is also dictated by economic and political pressures. With this model, it inevitably follows a top-down pyramid scheme, where the inhabitants are at the bottom. Buildings seem like they stand alone in the horizon, objects that are supposed to display authority and power of the company or owner. Their repeated typologies reflect a society that preaches diversity, but in reality, instills sameness. The complexity of the natural world is what is hardwired in us, and if we do not reflect it, our minds will be anesthetized from our environments. 


\section{CONTENTS}

FRONTISPEICE

ABSTRACT

OVINDOLI AND ALBERT STREET 2

PROLOGUE 3

INTRODUCTION

CHAPTER 1: THE MODERN CITY 8

CHAPTER 2: MEMORY, PURPOSE, AND THE $6^{\text {TH }}$ SENSE 17

- Proprioception and Graspability 17

- Memory-Perception 25

- Phenomenal Transparency 27

CHAPTER 3: INTERACTIONS WITH MIMESIS 31

- Paraticism vs. Mutualism 31

- Mirror Neurons 39

- Transformational Architecture 42

- Ambiguity 45

CHAPTER 4: SHEDDING THE BIASES 50

- Sharing Space 50

- The Individual Act 52

CHAPTER 5: EMERGENT ARCHITECTURE 60

- Extension of the Street 60

- The Site 61

- Structure 64

CHAPTER 6: UNCANNY DYNAMISM 72

ACKNOWLEDGEMENTS 78

BIBLIOGRAPHY $\quad 79$

IMAGE INDEX $\quad 80$ 


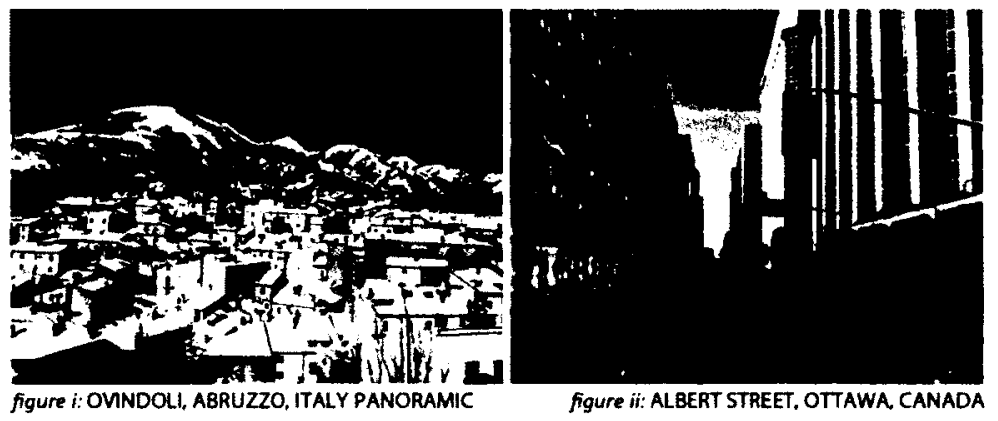




\section{PROLOGUE}

Upon reading the poetic discourse on the city in Juhani Pallasmaa's The Eyes of the Skin in my third year of Architectural Studies, I have shared the feelings of detachment and alienation that Pallasmaa describes. It seemed to me that this was mostly a North American problem, as I grew up in two rural towns in the Italian country side. Although I was born in Canada, I spent a good deal of my childhood in Tor San Lorenzo, a beach town fifty kilometres southwest of Rome. Through this experience, I have indirectly learned the value of proximity. Before walking to school, I would stop by Diego Bar with my mother (or grandparents) to get myself a ciambella and a cold glass of milk, a habit I had picked up in Canada (Diego the barrista would always call me "ll canadese" because of this). Along the way home, I would see classmates, family friends and acquaintances going about their day. We would stop to get bread, cold cuts, and whatever else was needed at the market. It would take on average about an hour to get home, sometimes more, even though it was a ten minute walk. On weekends, we would drive up to Ovindoli, my mother's home town in the Apennines of Abruzzo. I loved this place. It is a town that is about 700 years old that maintained its medieval urban fabric. It was a lot of fun for my sister and I to go for walks and explore the town, (even though we had been there hundreds of times) because of the exuberance and vitality Ovindoli displayed; small winding roads split into even smaller ones, stairs that would lead to areas otherwise inaccessible by the roads, leading to small grottoes with a bar and several homes; downhill paths framed by archways, leading to panoramic vistas of the mountains clearing a view of Avezzano, a city a thousand metres below; homes seemingly piled together in a sort of collage, volumes poking out at odd angles and potted plants and flowers placed where any space was available; the elderly hanging out together in the ledges of the main Piazza while children were playing soccer in the main square. Even with a population of roughly 1500 people and a climate similar to that of Ottawa (winters are cold and there is lots of snow), Ovindoli was always bursting with energy. 
Then we moved to Ottawa. I quickly realised the difference in lifestyle between the two cultures. I found myself coming home from school and doing absolutely nothing. I would go in my basement and play Super Nintendo until my mother would scream to go play outside. The problem was that, being twelve years old, it was not common for me to call up my friends to come over and play. Therefore, I would usually be alone (playing outside by myself got boring rather quickly). As I grew older and learned how to drive, I found myself always being in the car for any and every reason: driving to school, to my friends' houses, to work, to eat, to rent videogames/movies, to buy some groceries for my parents, etc. But perhaps more importantly, every house seemed the same to me. I remember a few of my friends' homes' that were built by the same developer; we essentially had the same house. When I would go downtown there were all these glass buildings. There was a disconnection. Anywhere I went in Ovindoli I felt at home, despite only being there on weekends. In Ottawa, I would only feel at home in my house, and I have resided there daily for fourteen years.

When I first read The Eyes of the Skin, it resonated with so much truth that I got the shivers. I knew that there was something that didn't feel quite right with the buildings of the modern city; not explicitly in their scale, but in the lack of vitality. Compared to Ovindoli, the modern city felt like a dead environment. I soon learned that the dynamism that emerged from Ovindoli was because it was a self-built environment. There was no developer; only craftsmen and masons. The town is comprised of multiple pieces all built one by one; with each new structure was a highly individualized form, because, of course, everyone is different. I realized that my experience in Italy, especially in Ovindoli, was a valuable one; one that could make me understand the value of self-built environments. But there was a gap in my understanding. I did not know what made them explicitly dynamic. Pallasmaa describes it as hapticity; where our bodies are measuring devices that connect to our environments. Yet to me, a lack of tectonic logic was not the source of the problem. What happens in our heads when we experience a town such as Ovindoli, versus a scene like Albert Street in downtown Ottawa? I felt that if I would further investigate 
into the realm of neuroscience I would see whether my feelings towards Ovindoli and Ottawa were not completely biased. Information linked from Vilayanur S. Ramachandran, John P.Eberhard and Harry Francis Mallgrave's neurological research to projects such as Ponte Vecchio, Maison de Verre, Hutong Bubble 32 and the Hong Kong Rooftop Villages (to name a few) has led me to a conclusion that we are hardwired to nature, and that in order for a city to feel like home, it must be built mutualistically without predefined notions of what a 'site' is. This process is natural and followed by natural law. For this to happen, it must be built individually by its inhabitants; not only by its corporations, developers, and government institutions. 
INDIVIDUAL ACT

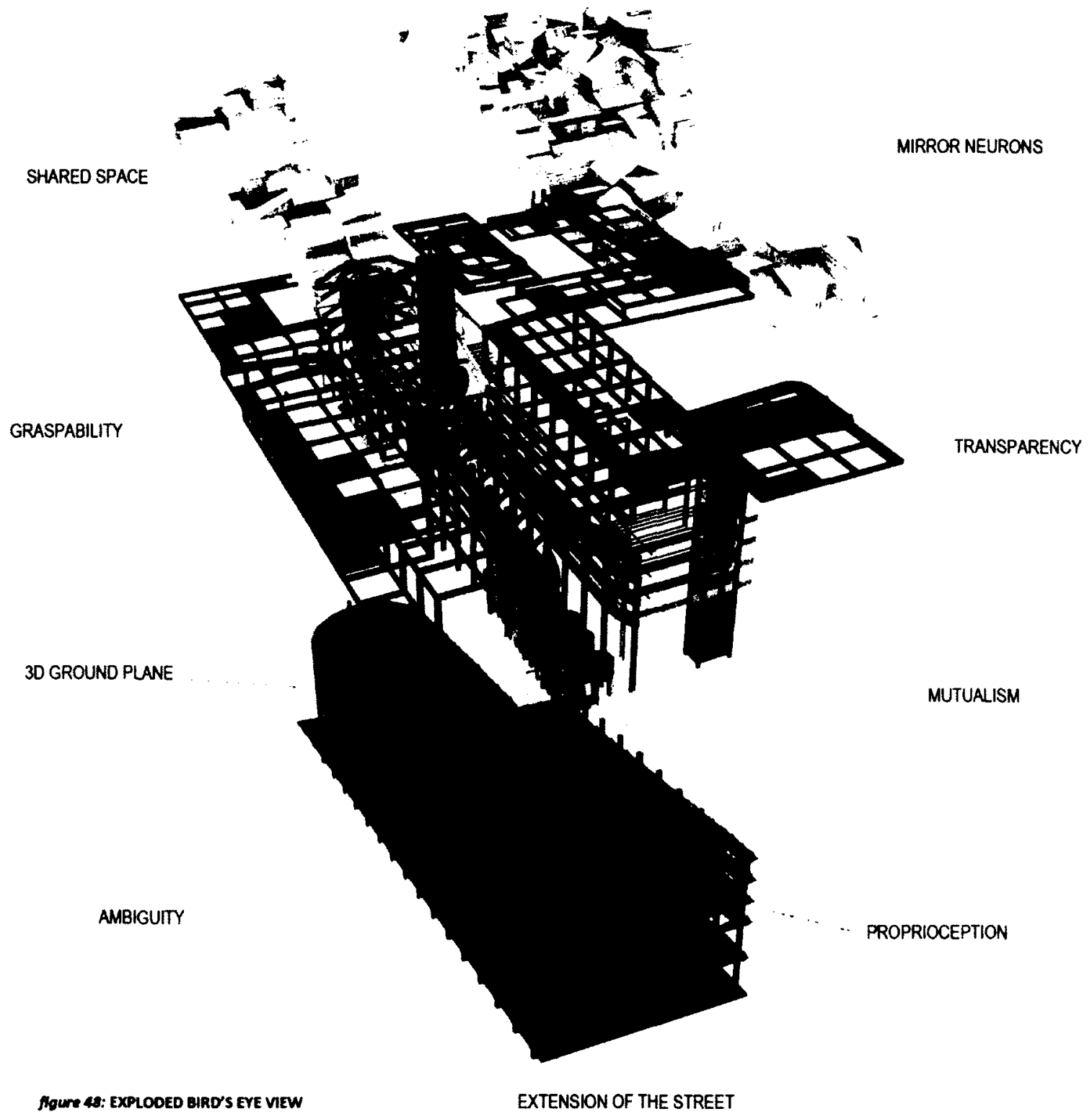




\section{INTRODUCTION}

How does the street interact with the architecture? This is often questioned when designing a building. This in essence singles out the street and buildings as mere objects. Large scale buildings are often extrusions of their footprint which invite only those for who it was built for. They do not offer any form of perceptual invitation in their space. How does architecture, interdependent with its program, extend the street so that the distinction between the two are blurred?

The city is a system. For emergent systems, the interactions of the components are not dictated by a higher power. The attributes listed should also manifest at different scales. For this to happen, the city cannot be built by top-down planning principles, since the building would be dictated by a higher power. We need to share built spaces that are unused by one but can present themselves as a potential intervention to another. It is the individual act, the component, which generates the form; a building system that starts from the ground up. The built environment could become more playful and experimental if people can choose where they want to build their dwellings.

If mirror neurons puts a person in the point of view of the other, making one feel as the other feels, both in emotion and action, then the modern city is disconnecting itself from its inhabitants. The transformation of architecture can thus be invigorating to the psyche if it is transformed relative to existing structures. This may be true for buildings as a whole, such as with Ponte Vecchio's shops and the Vasari Corridor; but it also holds true for functional programs as well. 


\section{THE MODERN CITY}

The problems of the modem city are nothing new. - Rhys Phillips'

In the urban core, we see glass box office buildings rising next to similarly bland apartment complexes abutting a gridded street plan. In the suburbs, miles of cookie cutter houses span the landscape only to be interrupted every few kilometres by strip malls or shopping districts. These problems are similar in many modern cities or districts of the world because they inherently have followed the same modernist design and planning strategies. Modernism praised the machine in both design and urban planning: building typologies reflected the processes of mass production since they were more economical than typical man-powered labour. With a few exceptions, this resulted in the box: their orders then followed the same rationale within a mechanistic and purist framework. Rhys Phillips, at a lecture given at the RAIC in 2003 , claimed that " $95 \%$ of what is built in Canada today can best be described not as architecture but as competent building technology $y^{2}$." He went on to say that "architecture is not simply a narrowly functional exercise. Rather it is the art of providing tools that

\footnotetext{
${ }^{1}$ Phillips, Rhys. "Avoiding Extinction: Architecture, Place and Politics. "OAARAIC, 2003. Web. 
permit us to dwell, that help us define in a meaningful way our relationship to both our natural and social environments ${ }^{3}$."

Lion Barshack, in his article The Consituent Power of Architecture claimed that "the postmodernist writings of Deleuze, from which key terms such as smooth space, folding, pliancy, and so on, have been transmitted into a new impetus for morphogenesis of the generation of a new form in architecture adopted by many architects such as Zaha Hadid, Frank Gehry, Thomas Mayne and Daniel Liebskind." In taking an oppositional stance to the modernist resolution of universalization of space, through a structured organisation of pure forms, postmodernist architects express the heterogeneity with the invention of new forms that are more representative of the psychic and social fractures of modern life. Barshack also stated that folded surfaces and smooth forms become rapidly adopted by these architects seeking new ways to convey the inherent contradictions of our society and reflect the many and new different forces that simultaneously act on the design ${ }^{4}$.

Yet, there is still an inherent sense of control. Modernism, especially in North America may have hyper-rationalised programmatic space, but Deconstructivist architecture of Free-Form continues to instill a sense of control, a fixed product for human dwelling, by applying computational devices to predict and generate forms; yet the search for new typologies are noble ones as they offer diverse spatial experiences.

\footnotetext{
${ }^{3}$ Phillips. Ibid

${ }^{4}$ Barshack, Lion. "The Constituent Power of Architecture." (2010). Print.
} 


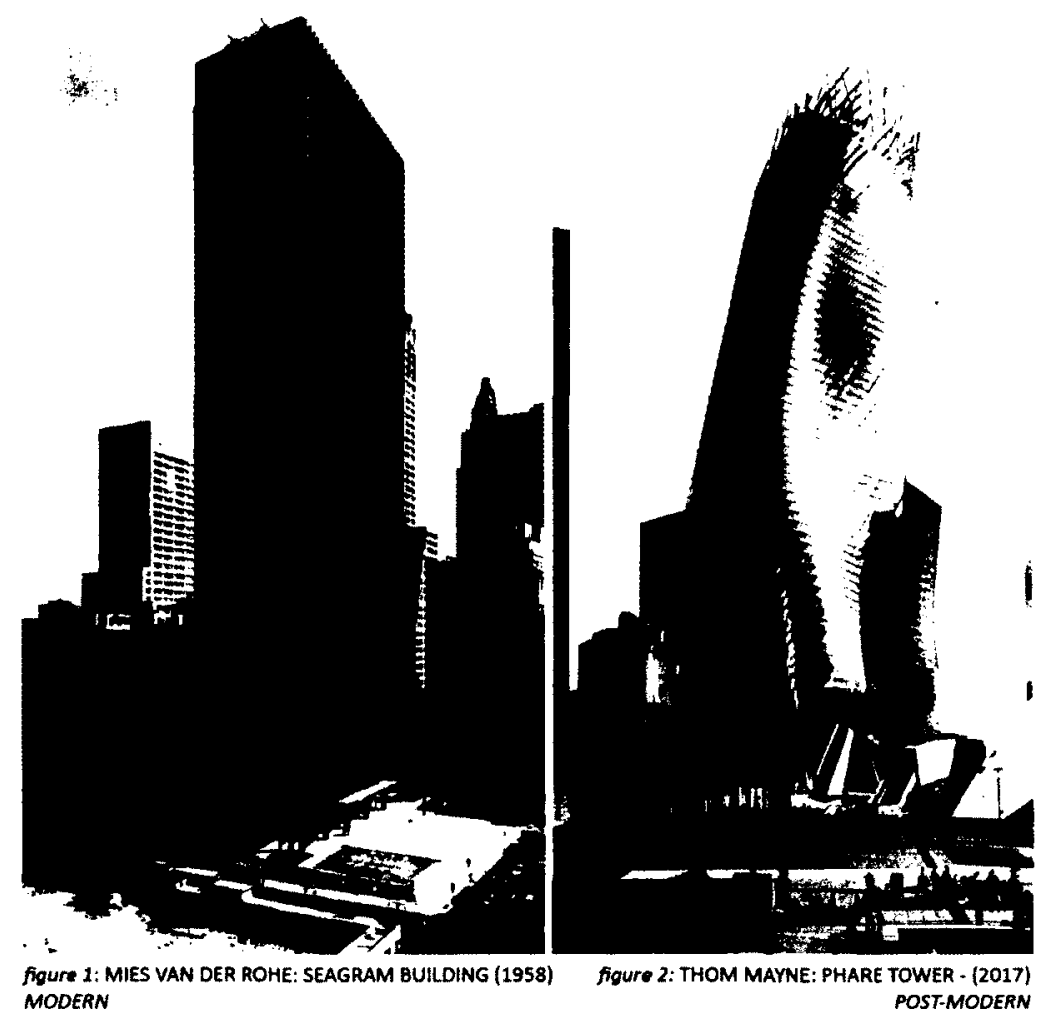

But the redundancies seen in modern architecture go beyond form; postmodernist architecture seems to be a differentiation, maybe an evolution of design, but it does not take into consideration the human condition because architecture, is of course, primarily a function of its client. As both a functional craft and an expressive art that carries a high object cost, it is seldom speculative requiring instead a substantial bankroll. As for Phillips, he claims that "developers, public and quasi-public institutions, our commercial institutions and, increasingly, the accountant dominated pension and trust funds that bankroll huge sectors of our built environment, the concept of architectural patron is dwindling ${ }^{5}$."

The Generic City, explains Rem Koolhaas in the book SMLXL, "is a place of weak and distended sensations, few and far between emotions,

\footnotetext{
${ }^{5}$ Phillips. op.cit.
} 
discreet and mysterious like a large space lit by a bed lamp. Compared to the classical city, the generic city is sedated, usually perceived from a sedentary position ${ }^{6} . "$ Perhaps Juhani Pallasmaa, Finnish architect and theoretician comes closer to identifying the problem in the book The Eyes of the Skin by claiming that architecture forming our cities is devoid of haptic experience. Hapticity is related to touch and its dominating importance in our bodies, as described by anthropologist Ashley Montagu, is paramount:

[The skin] is the oldest and the most sensitive of our organs, our first medium of communication, and our most efficient protector... Even the transparent cornea of the eye is overtain by a layer of modified skin... Touch is the parent of our eyes, ears, nose, and mouth. It is the sense which became differentiated into other, a fact that seems to be recognized in the age-old evaluation of touch as "the mother of the senses"?

The current industrial mass production of visual imagery tends to alienate vision from emotional involvement and identification, and to turn imagery into a mesmerising flow without focus or participation. Michel de Certeau, a French Jesuit and scholar whose work combined history, psychoanalysis, philosophy, and the social sciences perceives the expansion of the ocular realm negatively indeed:

From television to newspapers, from advertising to all sorts of mercantile epiphanies, our society is characterised by a cancerous growth of vision, measuring everything by its ability to show or be shown, and transmuting communication into a visual joumey. ${ }^{8}$

The visual journey is a short one if relayed into one image since spatial experience is a series of overlapping images. Since society is in a hurry, it

\footnotetext{
${ }^{6}$ Koolhaas, Rem, and Bruce Mau. SML XL: OMA. S.I.; S.n., 1993. Print.

'Pallasmaa, Juhani. The Eyes of the Skin: Architecture and the Senses. Chichester: Wiley-Academy, 2005. Print.

${ }^{8}$ Harvey, David. The Conditions of Postmodemity, Blackwell (Cambridge), 1992, p.293
} 
relies on metric schemata: travel time, distance, street number, floor number, and directions such as three doorways to the left to guide its movements since visual features are insufficiently distinctive to form a memorable picture of the path. Areas with high variety (entrance lobbies, halls etc.) are simplified. Harold M. Proshansky in the journal Architecture for Human Behaviour claimed that "while functional, these symbols are detached for sensory richness and quality of experience, which is what influences the scope character and utility of comprehension of the world. They ignore habits of life, cultural traditions, or personal aesthetics ${ }^{9}$.

In fact, metric schemata negate any possible perception that can be directly obtained with what it is representing; to form ideas, conclusions about the object in question. It has no physical, experiential basis to the real world. Psychologist Leon Festinger coined this phenomenon as cognitive dissonance: a state of affairs that occurs whenever two ideas are in conflict with each other. The brain searches for physical information to bridge the two seemingly diverse ideas, but cannot since metric schemata are purely symbolic. This allows for behaviours of withdrawal by ignoring the perceptual problem:

The image so developed now limits and emphasizes what is seen, while the image itself is being tested against the filtered perceptual input in a constant interacting process. - Kevin Lynch ${ }^{10}$

Symbols and physical cues are different. For example, the iron bars on a gate read as do not enter; as a do not enter sign attempts to incorporate the feeling that the iron bars project. Conversely, a person in his or her

\footnotetext{
${ }^{9}$ Proshansky, Harold M. Architecture for Human Behaviour Environmental Psychology and the Design professions. 1970

${ }^{10}$ Lynch, Kevin. The Image of the City. Cambridge [Mass.: Technology, 1960. p.6. Print.
} 
home can be understood because architecture presents itself in terms of a setting for behaviour, a physicality to respond to ${ }^{11}$. But how does this fundamental reference process in the brain? Often, talk about architecture happens in specific cases; the success of buildings in their design, program, detailing, technological innovation, etc. as it pertains to the building itself. But how does it relate to the environment? This question may seem obvious. Some buildings may offer a program that is relevant to the site; some may use materials that reflect the urban fabric; some may even imitate forms found in the character of the neighbourhood; some may relate to it with purely rational geometric associations. But perhaps, the question itself may be a loaded one. It assumes that the building is merely an object that sits in its environment; while in fact, it is part of an environment; an extension of the landscape. In that sense, it is not strictly an object.

Objects are the most intimate form of construction as they deal with specific uses. It gives out a sense of purpose since its shape and scale are a direct reflection of its specific use, like an apple on a tree is to be eaten, or a step on a stairway is to be climbed. Smaller scales of architecture possess this characteristic as behaviours are highly varied yet specific to the size of the spaces; they approach the quality of an object, since it is physically and behaviourally understood, while a glass skyscraper is a massive construction thus one cannot physically tell what its intended function is. The skyscraper holds a collection of spaces which concentrate into spaces with specific uses, but their facades make them illegible. They

\footnotetext{
11 Proshansky. op. cit.
} 
can be intellectually reasoned but their activities are not felt with the body. This means a number of things: the spaces are hidden, thus they cannot be understood but also, perhaps more importantly, the path towards them is hidden, so people cannot perceive how to physically explore them. They are alienating because they are not perceived, but their existence is still known. A home in a residential neighbourhood is much more intimate, since its scale can be understood as a direct relationship to the behaviours and the inhabitants of that space. Generally, one family lives in a house; since most people live in a house with a family, the main activities are similar; cooking, cleaning, sleeping, watching the television, etc. The tools and spatial requirements needed for these activities are similar as well: a kitchen, pots and pans for cooking, a broom for cleaning, a bed in a bedroom for sleeping and a couch in a living room for watching television. The mental associations become imprinted in the brain and, as a matter of fact, mirror neurons ${ }^{12}$ could literally activate the same feelings of being home by merely looking at a house; even if a person is not there (the feeling of empathy is created). The way to the entrance can also be seen. The street in this case acts like the corridor of the skyscraper. It holds the series of houses on that street. How inviting a neighbourhood feels is correlated to the availability of the activities that are present by the surrounding architecture. This would allow an empathetic relationship with the behaviours associated with being home. While in the skyscraper, the passerby cannot access the circulation which builds the bridge to perceiving the activities within that building.

\footnotetext{
${ }^{12}$ described in chapter 3
} 
Fundamentally, buildings are organizations of matter that suit a program, just as nature crafts organic matter to make environments for all living things. The difference is that the organisms found in nature use every nook of space to house different sites for a diverse range of species; there are complex chemical and spatial relationships between them, in three dimensions, to maximize use of space and conserve energy. They share space, without interfering, so that every creature has his or her optimal dwelling. So for all purposes and intent, the question shall be changed into a statement: The built is the environment. This notion redefines a site not only as a flat piece of land, but anywhere where there is potential for an implementable behaviour. This is to create more space with less of it, by continuously searching for new possibilities on existing buildings. ${ }^{13}$

This redefinition of space has huge implications. In pre-industrial towns, proximity was paramount, thus people built their dwellings wherever there was space available. One could say that the scarcity of space required that to happen, but at the same time, this frugality only heightened the importance of space, hence being treated with more care by the individual and his family. Neuroscience and the other cognitive sciences demonstrate that acts of creation are ever present, not just with architecture: how people dress themselves, how they cook, how they write... are all inherently creative individual acts.

\footnotetext{
${ }^{13}$ See poché, chapter 3
} 


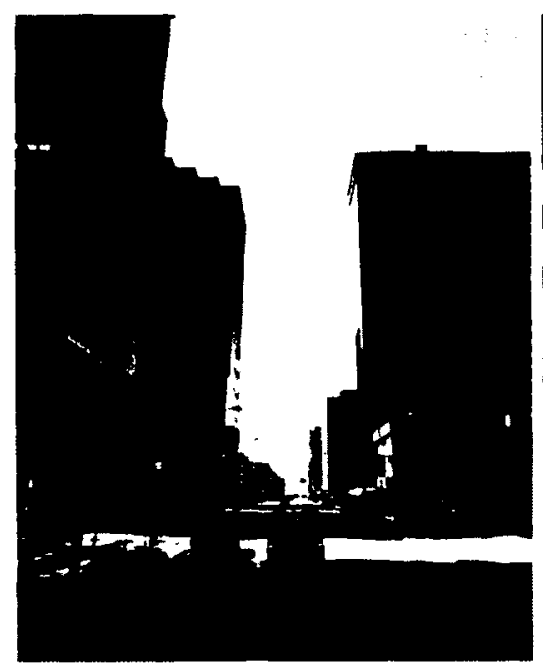

figure 3: ALBERT St., OTTAWA, CANADA MODERN CTTY

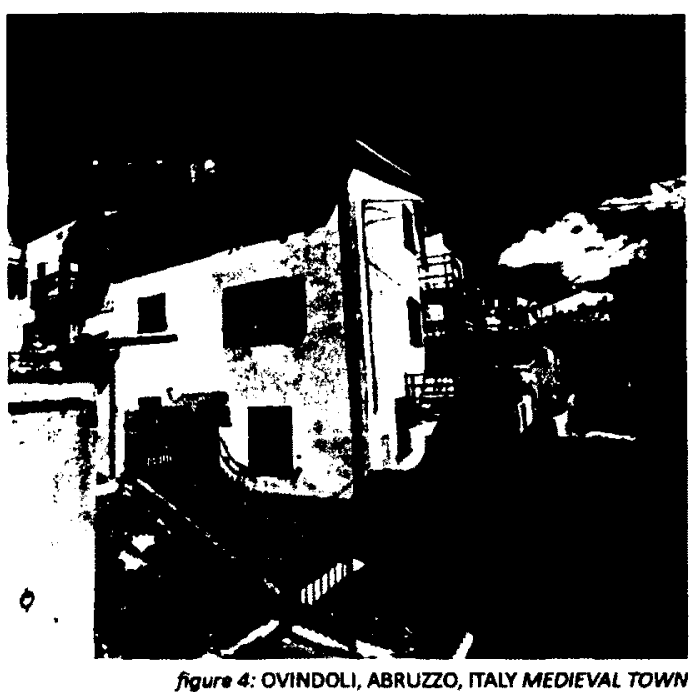

figure 4: OVINDOLI, ABRUZZO, TTALY MEOIEVAL TOWN

Buildings need to be physically and emotionally understood, if not they will in unison create an alien, emotionless and bland environment. Many contemporary theorists have delved into the reasons of why this is so, but with little scientific basis. Science can help peer through the human psyche and explain why the modern city is alien while demonstrating how the brain is hard-wired to nature. The perception of the man-made world uses nature as its model, but fundamentally, it will show just how much humans are connected to the environments they create. This ground will be paved by historical and modern architectural events that display an uncanny dynamism where the freedom of individual acts becomes the engine of an emergent architecture. 


\section{MEMORY, PURPOSE AND THE 6TH SENSE}

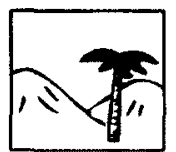

Understanding architecture implies the unconscious measuring of an object or a building with one's body, and projecting one's bodily scheme on the space in question. We feel pleasure and protection when the body discovers its resonance in space - Juhani Pallasmaa ${ }^{14}$

\section{Proprioception and Graspability}

The first step to understanding ourselves in context to our surroundings is by the sixth sense of proprioception since it tells us where our body is in space $^{15}$. Visual conscious awareness acts as a series of static snapshots filled in with motion in one of the visual cortices (V3 area) of the brain. These snapshots are experiential and are reinforced when looking at a building in question, by the series of snapshots preceding it. If they follow the narrative of the experience, the brain will bind together the nodes of what you are currently experiencing with what you had experienced in the past ${ }^{16}$. For example, the

\footnotetext{
${ }^{14}$ Mallgrave, Harry Francis. The Architect's Brain: Neuroscience, Creativity, and Architecture. Chichester, West Sussex, U.K.: Wiley-Blackwell, 2010. Print. p.121

${ }^{15}$ Eberhard, John P. Architecture and the Brain: a New Knowledge Base from Neuroscience. Atlanta, GA: Greenway Communications, 2007. Print. p.46

${ }^{16}$ Mallgrave. op.cit. p.122
} 
first two levels of the C.D. Howe Building in Ottawa is a mall. The building is basically a glass box.

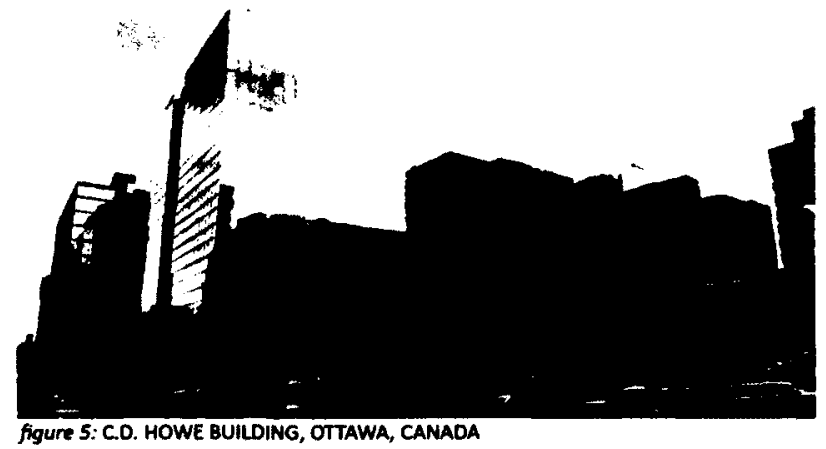

In terms of experience, there is nothing alluding to the fact that there is a mall in the building. One cannot see the path, or the series of snapshots provided by the environment leading to that point. The only indication is that there are a couple of inaccessible store fronts, and a slightly recessed entrance with doorways (metric schemata). Conversely, the Alto Palermo Plaza in Buenos Aires and Korea's Ssamziegil Mall's entries are not marked by a door, but by extensions of the street, where one can see the behavioural aspects of being inside the mall. In other words, the passerby can see the activity, the movement of the people, their expressions, etc. This sudden change in direction and program as seen with the examples above, is marked by what some call a eureka, or aha moment. To paraphrase Harry F. Mallgrave, it is usually attributed to the feeling one gets when an element of positive surprise comes into play, whether when a problem is solved, or the moment of a creative breakthrough, or even in word problems. ${ }^{* 17}$

\footnotetext{
* In a laboratory in Northwestern University in 2006, a team of Neuroscientists from three universities, led by John Kounios and Mark Jung-Beeman, conducted two experiments in which they attempted to peer into that "Eureka" moment with the use of EEGs (electroencephalograms) and fMRIs (functional Magnetic Resonance Imaging). One of the first areas of the brain to become involved is the ACC (anterior cingulate cortex), which is a center of the brain which deals with maximising focus by suppressing irrelevant perceptions, which begins by accessing the semantics of the situation. The "Eureka" moment is characterized by a burst of gamma frequency (a type of brain wave. There is alpha, beta, theta and gamma) on the opposite side of the
} 


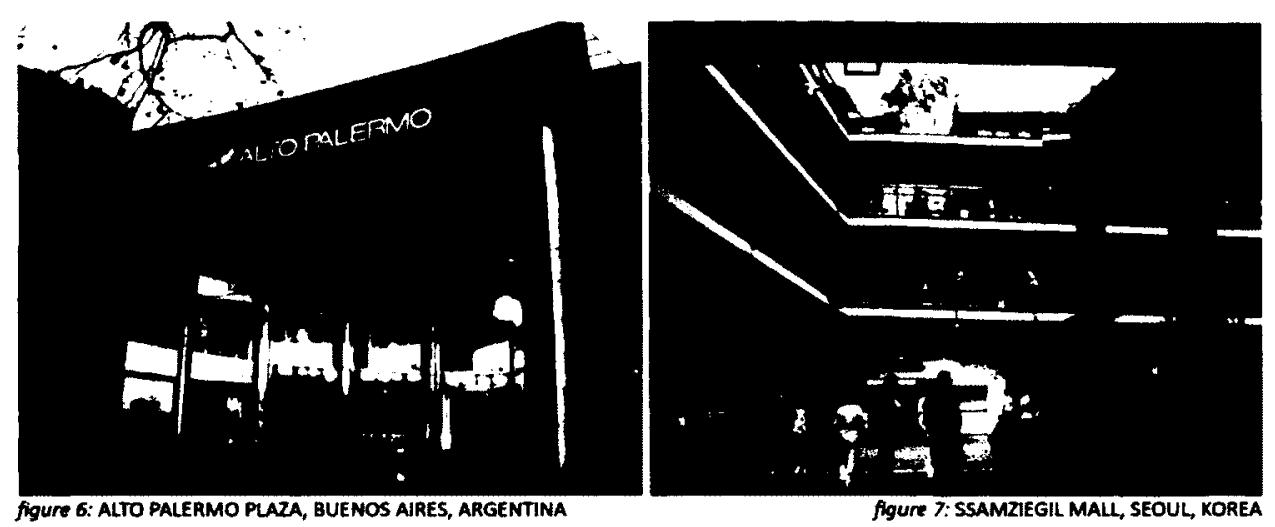

The senses are a collection of perceptual activities led by neurons in the brain which are co-existent with the motor-system. Vision is largely a process of problem solving. According to neuroscientist V.S. Ramachandran in the book The Tell-Tale Brain, the human brain struggles when there is an object in a scene that is subject to coincidence. Ramachandran explains this scenario with the following: the drawing of a tree (a) is placed between two mountains in the background produce a perceptual anxiety because it is coincidental without an explanation. That a tree would grow in a spot exactly between two mountains is beyond comprehension; one cannot interpret the coincidence. By placing it in the center, it gains importance over the whole scene since it fills the void between the mountains. It seems like the mountains are there only to create a space for the tree; the path is closed where the final destination is the tree. On the other hand, the tree in (b) is placed slightly off center. Since it is not framed symmetrically, it retracts from landscape and does not impose a dominance of importance. Similarly, large buildings that stand alone, such as towers and skyscrapers, could produce the same effect because each building is an environment that encloses the space within, thus

brain: the right anterior superior temporal gyrus. This means that even word problems are not solved in the language area of the brain, but a more creative, spatial and associative area.

${ }^{17}$ Mallgrave. op.cit. p.171-172 
framing its own dominance over the landscape. There is no open ended sequence of spaces that lead the body to explore the scene. This isolation in contrast with the illegible path could be alienating. In art and architecture, according to Ramachandran, "it is usually about reaching a middle ground between orderliness and chaos where the element of surprise comes when there is a shift in orders ${ }^{18}$." These are perhaps a product of place cells (discovered in the 1980s) that deal with recognizing places; not exactly imbued with meaning, such as a house, or a church; but rather the ability to conceive what a space is by knowing where it lies between certain geometric boundaries.

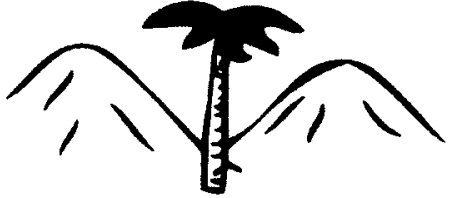

(a)

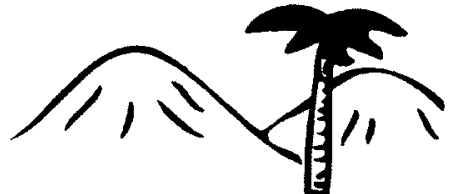

(b)

figure 8: FIGURE (a) IS A TREE BETWEEN TWO MOUNTAINS WHILE FIGURE (b) IS THE SAME TREE SLIGHTLY OFFSET

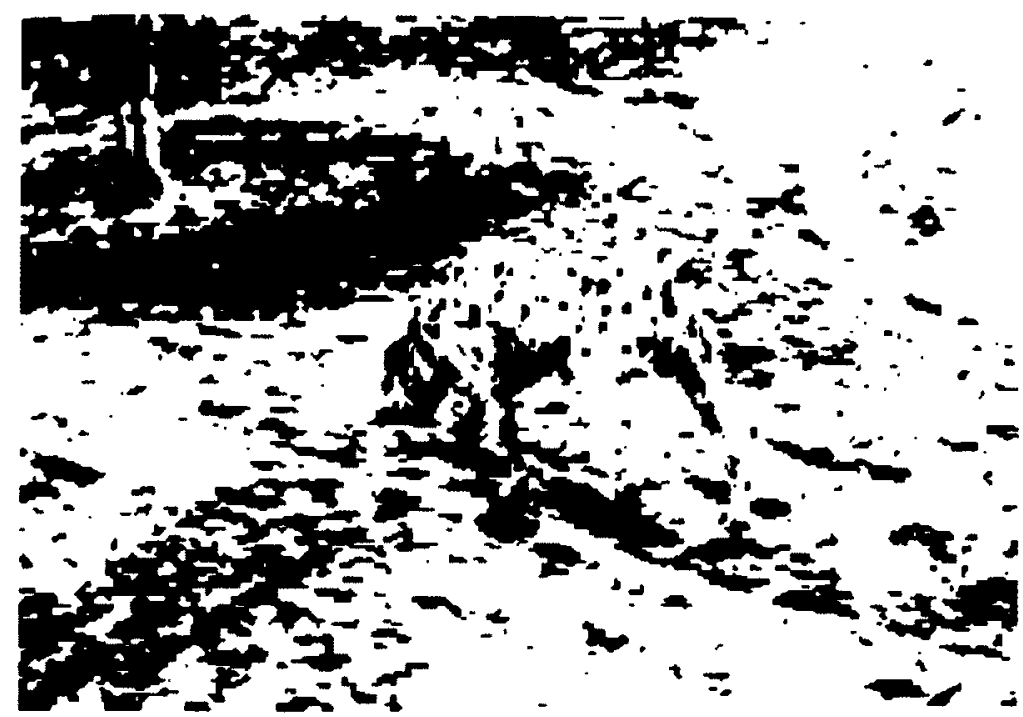

figure 9: Ploce cells: WHAT DO YOU SEE? IT LOOKS UKE RANDOM SPLATTERINGS OF BLACK INK AT FIRST BUT WHEN YOU LOOK LONG ENOUGH YOU CAN SEE THE HIDDEN SCENE.

\footnotetext{
${ }^{18}$ Ramachandran, V. S. The Tell-Tale Brain: A Neuroscientist's Quest For What Makes Us Human. New York: W.W. Norton, 2011. Print.
} 
Furthermore, in 2005, a group of Norwegian scientists discovered grid cells, which function like a laser scanner, or sonar, which provide a topographic map. To paraphrase Mallgrave, they give information about paths within the spatial environment. ${ }^{19}$ By observing the combination of the activity of grid cells and the perceptual problem solving the brain likes to be involved in to achieve these eureka moments, it can be surmised that the more complex (not complicated) and dynamic the environment is the more these gamma activities are activated in the brain.

The relationship with that kind of multitude of spatial events seems to be grounded in the some of the most ancient parts of the brain. In combination with place cells and grid cells, there is a neural pathway concerned with spatial aspects of vision: the Old Pathway. The Old Pathway knows where, but not what, an object is. It enables the body to orient toward objects and track them with its eyes and heads where "the visual scene in nature is the landscape and is set in place in order for us to closer ratify and come in contact with objects that can be used for our manipulation; they are the purpose of our search, the reason why we navigate through the landscape ${ }^{20}$."

Antonio Damasio, Professor of Neuroscience at the University of Southern California, raises the possibility that the understanding of feelings "can inspire the creation of conditions in the physical and cultural environment that promotes the reduction of pain and the enhancement of well-being for society ${ }^{21}$." Research by Jaak Panskeep, Estonian-born American psychologist, psychobiologist and neuroscientist suggests that if such a thing is to be

\footnotetext{
${ }^{19}$ Mallgrave. op.cit. p.196

${ }^{20}$ Ramachandran. op.cit.

${ }^{21}$ Mallgrave. op.cit. p.191
} 
achieved, the environment must somehow communicate with the human being's most primal attributes. Panskeep identifies seven endophenotypes, or core emotional instincts, that are found in all mammals; seeking, lust, care, panic, rage, fear, and play. Two of these - seeking and play - are vital to the various fields of artistic creation and appreciation.

Seeking (and its emergent emotions of curiosity, anticipation, and interest) has been long viewed as a cornerstone of human nature. Edmund Burke termed curiosity and its pursuit of novelty the "simplest emotion we discover in the human mind, otherwise life would habituate itself of loathing and weariness ${ }^{22 "}$. Neuroscientist Kenneth Heilman has termed novelty as "a major criteria of creativity and related it in the visual arts to the manipulation and transformation of images ${ }^{23}$." It can then be surmised that an environment with many spaces, or defining boundaries, can be more stimulating than ones that do not, simply because they enable a position in space to be found in order to solve the perceptual problem of where an object or a goal is located. Objects are always used: a mouse to navigate a computer, a mug to drink coffee, a pot to cook in and they always seem to be symmetrical. People tend to prefer symmetry when it pertains to usable objects, not to large scale scenes. Ramachandran claims that this makes evolutionary sense because "a predator, a prey, a friend or a mate is always an isolated independent object ${ }^{24}$." So the detection and enjoyment of symmetry is based on object-centered algorithms in the brain, not scene-centered ones. To this model, each time a partial fit is discovered, a small aha is generated in the brain. This signal is sent to limbic reward structures, giving pleasure, which in turn prompt the

\footnotetext{
${ }^{22}$ Mallgrave. op. cit. p.192

${ }^{23}$ Mallgrave. ibid. p. 192

${ }^{24}$ Ramachandran. op. cit.
} 
search for additional or bigger ahas, until the scene or object crystallizes.

These ahas are linked to phenomenological instances because they are in context to how a space or object can be used, thus meaning that the line between action and perception becomes blurred.

This link between action and perception has become especially clear in the last decade - with the discovery of a new class of neurons in the frontal lobes called canonical neurons. Likewise, each canonical neuron fires during the performance of a specific action such as reaching for a vertical twig or an apple. But the same neuron will also fire at the mere sight of a twig or an apple. In Ramachandran's words, "it is as though the abstract property of function were being encoded as an intrinsic aspect of the object's visual shape. The distinction between perception and action exists in ordinary language, but it is one that the brain evidently doesn't always respect ${ }^{25}$. This might be useful for understanding why a textured surface is compelling to touch. The surface is read it as rough, smooth, soft, etc., which means a person has already, to some extent, experienced the object. Ramachadran refers to this phenomenon as graspability.

Graspability is closely related to what 18 th Century German Philosopher Emmanuel Kant called purposiveness. He describes this concept "as a subjective and heuristic principle, that is, it resides in our brains and therefore is not something that exists within the object ${ }^{26 " ;}$ rather it is the interpretation of how one can use the object. The purpose given to an object is personal and depends on someone's life experience. Kant relates this concept to works of art, claiming that "art should possess some kind of inner form that

\footnotetext{
${ }^{25}$ Ramachandran. ibid.

${ }^{26}$ Mallgrave. op.cit. p.55
} 
implicitly, at least, mirrors the principles of nature ${ }^{27} . "$ This is important because the environment is presented like a library. All the books are present and are seen, which in turns mean they can be accessed. Since everyone is different, a different book will be chosen by each person. Space works in the same way. Dimensions of a space can vary depending on its the use. Similarly, creatures in the natural world can co-exist because they can find different uses of space within the same environment. A dynamic environment is accompanied with its materiality and forms that elicit specific bodily responses. Furthermore, this difference is not hardwired, or biological. Ramachandran located this process in what he calls the New Pathway in the brain. This pathway, as opposed to the Old pathway, deals partly with "relationships among visual objects or scenes in space, in which the associations are created after birth. The New Pathway determines the overall spatial layout of the visual scene rather than just the location of an object. It has very strong links to the motor system and most of these functions are unconscious and automated ${ }^{28 n}$, as mentioned with the canonical neurons. Furthermore, neuroscientists Irving Biederman and Edward A.Vessel argue that the brain is hardwired for pleasure which lead to the aforementioned aha moments. Their theory proposes that "the rate of endomorphins (a neuro-transmitter) release in the area of the brain called the parahippocampal cortex determines, at least partially, the human preference for experiences that are both novel and interpretable ${ }^{29}$." That is, these new experiences activate a large set of associations with past experiences, where there is that aha moment, or a click of increased pleasure from understanding a scene. Their theory also suggests that people "typically experience an

\footnotetext{
${ }^{27}$ Mallgrave. op. cit. p.55

${ }^{28}$ Ramachandran. op. cit.

${ }^{29}$ Eberhard. op. cit. p.96
} 
adverse reaction to perceptual inputs that are processed in the brain more slowly than the rate of comprehension ${ }^{30}$." These could be attributed to architecture where a street with towers is seen, but not spatially comprehended since the brain is generally looking for different paths, or physical cues to lead it to a goal, or object. It can then be surmised that metric schemata do not provide these carnal experiences. A branch of a tree, for example, will give us the possibility to climb. Similarly, a building such as the Palazzo Medici, with its large stone blocks at its base, can elicit a similar thought.

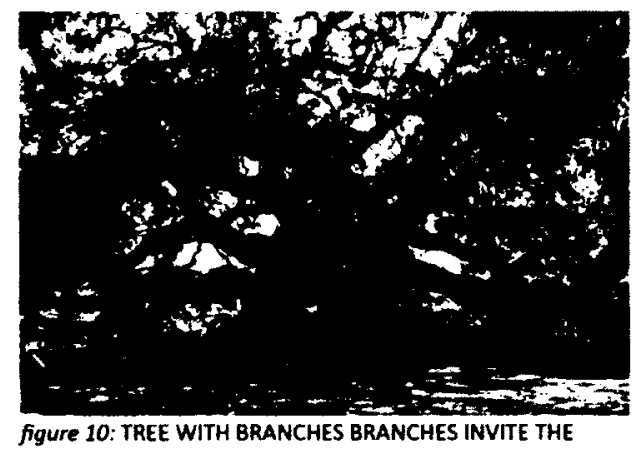
figure 10: TREE WIT
BODY TO CUMB

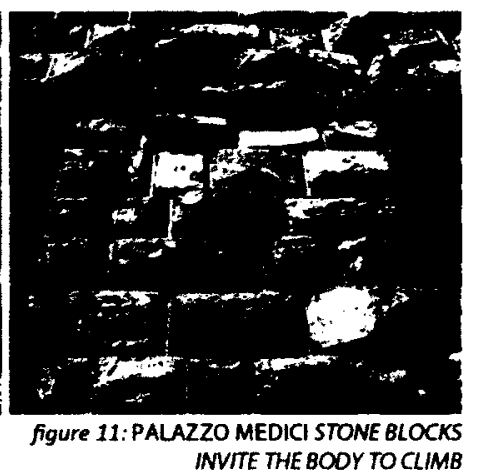

\section{Memory-Perception}

Dr. Gerald Edelman, Director of Neurosciences Institute of San Diego, suggests that each person "is born with a primary repertoire of neuron clusters, hundreds or even thousands of Neurons whose dendrites are integrated (Old Pathway). Later, as the world is experienced, a secondary repertoire is formed - building on material from the primary repertoire ${ }^{31 "}$ (New Pathway). Thus people are constantly building their memories while strengthening old ones that are stored in the brain. This means that the memory of things, the property of things, persons and places, events and relationships - exist in dispositional form (a special record filed in the brain), waiting to become an explicit image or

\footnotetext{
${ }^{30}$ Eberhard. ibid. p. 96

${ }^{31}$ Eberhard. ibid. p.70-71
} 
action. Dispositions are the records of events a person once perceived including the motor adjustments of muscles made to obtain the perception in the first place and also include emotional reactions. Edelman claims that "consequently, when someone merely thinks about an object, he or she will tend to reconstruct memories not just of a shape or color but also of the perceptual engagement the object required and of the accompanying emotional reactions, regardless of how slight ${ }^{32}$." The distinction between perception and memory is not great, as they are intimately connected; to perceive, by definition, is to have already conjured up an associative memory that is linked to a specific action. To paraphrase Edelman, even when an individual calls up the mental image of a building, the same patterns of activity in the brain can be observed as when the individual is actually are looking at the building, akin to looking at a branch. ${ }^{33}$ If the environment that surrounds that individual is devoid of stimuli that trigger our sense of proprioception that engages the body with its spatial surrounding, it can thus feel alienating and rejecting. If these perceptual signals are constantly fired, these circuits can only become more intensified with each firing. These amplified maps will then have an advantage over the other maps in the brain's processing of memory and thought. ${ }^{34}$ As neuroscientists like to say: "Neurons that fire together, wire together."

\footnotetext{
${ }^{32}$ Eberhard. op. cit. p.104

${ }^{33}$ Eberhard. ibid. p. 106

${ }^{34}$ Mallgrave. op.cit. p. 207-208
} 


\section{Phenomenal Transparency}

[Phenomenal] Transparency in this sense is a property of active mental representations already satisfying the minimally sufficient constraints for conscious experience to occur. Some of these constraints might even be necessary conditions - Thomas Metzinger ${ }^{35}$

Proprioception and graspability are closely tied to each other: in order for someone to understand where they are going, they need to have a physical understanding of the space they are exploring, both volumetrically and in a utilitarian way. The procession between a space and a more distant one needs to have level of transparency in its interstitial spaces. This allows a path to be formed between these spaces that lead to a final destination. The physical structures in the environment are only perceived when they become mental structures. In the article Event Perception, Gunnar Johansson, Gunnar Jansson and Claes Von Hofsten claim that "these mental structures are what constitutes the environment as a series of usable objects and, since they are linked to motor commands, imply how they can be used ${ }^{36}$." A moving point of observation is necessary for any adequate acquaintance with the environment. Metzinger also claims that "one must perceive in order to move but one must also move in order to perceive ${ }^{37}$." For different phenomenal stateclasses resulting from different types of processing, it may also be possible to describe not only variable degrees, but distinct kinds of transparency and opacity: "this allows for a much more realistic description of certain phenomenological features pertaining to different classes of conscious

\footnotetext{
${ }^{35}$ Metzinger, Thomas. "Psyche." Précis: Being No One 11.5 (2005): 10. Print.

${ }^{36}$ Johansson, Gunnar, Gunnar Jansson, and Claes Von Hofsten. "Event Perception." Annual Review of Psychology 63rd ser. 31.27 (1980): 320-57. Print. 38

${ }^{37}$ Johansson, Jansson, Von Hofsten. ibid.p. 48
} 
states $^{38}$. "In other words a space may become perceived depending on what a person is looking for. In order for this to happen the perceiver must know, by association or direct experience, what space is required for the activity crystallises. Yet by guiding attention towards a perceived object, a selection and an enhancement is achieved. By turning towards the phenomenal representation of an object, the brain automatically intensifies the information processing in the brain, which underlies it. Typically the object becomes more salient in this act, it becomes richer in detail and more coherent by being segregated from a background at the same time - a new and better representation is generated ${ }^{39}$. This could happen when the construction is legible and expressed; a smaller scale structure with a pitched roof may invoke a feeling of home.

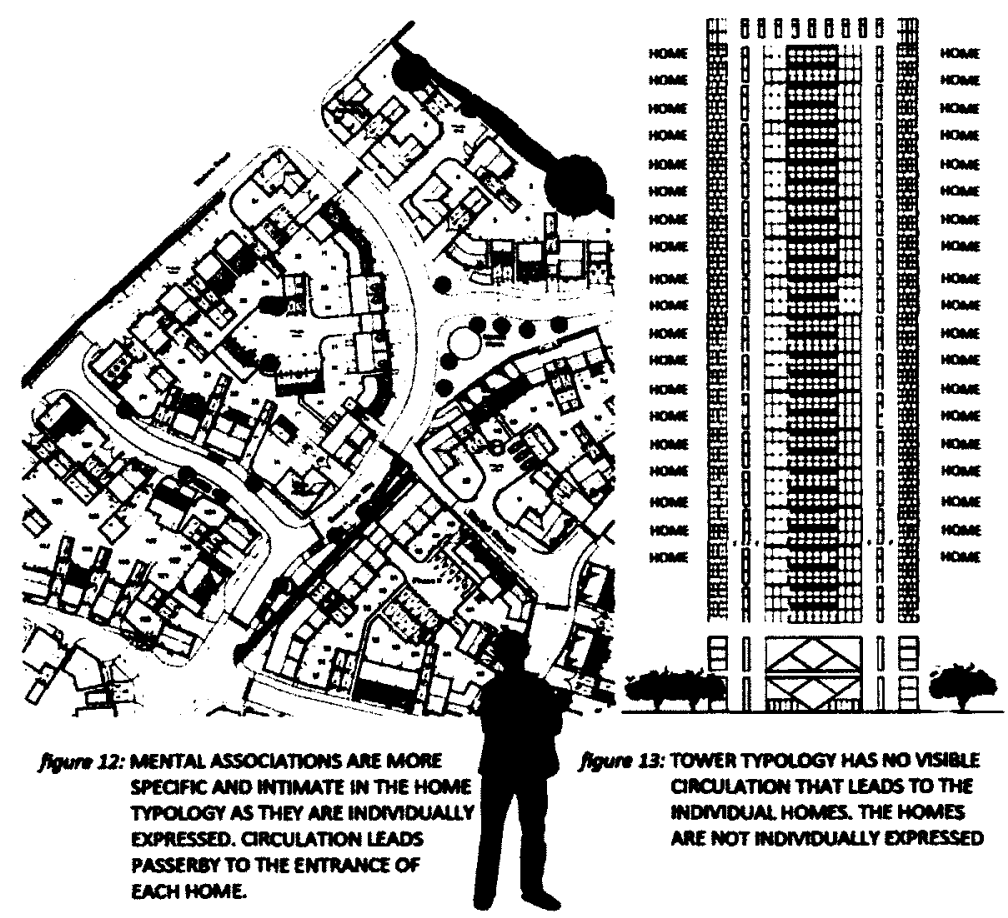

\footnotetext{
${ }^{38}$ Metzinger, Thomas. "Phenomenal Transparency and Cognitive Self-reference."Phenomenology and the Cognitive Sciences 2.4 (2003): 353-93. Print. p.358

${ }^{39}$ Metzinger. ibid. p.358
} 
Conversely, the relationship between planes may express a void. This void can take shape spatially as usable space but also functionally and intellectually, where there is an ambiguous play between architectural elements. $^{40}$

Sigfried Giedion claims that in "Picasso's L'Arlesienne, the picture that provides the visual support for these inferences, such a transparency of overlapping planes is very obviously to be found. In the laterally constructed space of his picture, Picasso, through the compilation of larger and smaller forms, offers the limitless possibilities of alternative readings, while the glass wall at the Bauhaus, an unambiguous space, seems to be singularly free of this quality ${ }^{41}$.

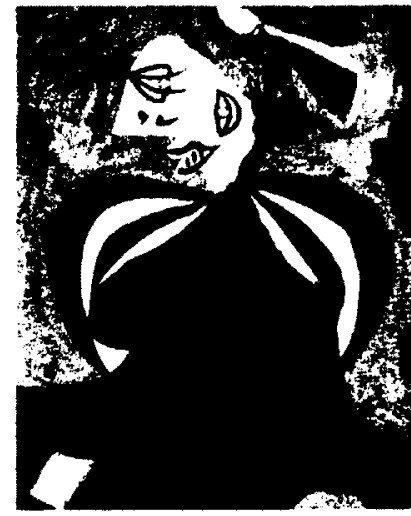

figure 14: L'ARLESIENNE - PABLO PI. CASSO PHENOMENAL TRANSPARENCY CREATED BYOVERLAPPING DISTN GUISHED OBJECTS

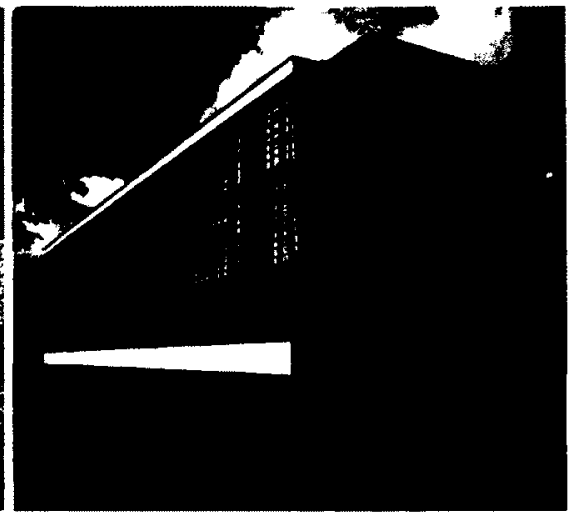

figure 15: BAUHAUS - WALTER GROPIUS - LITERAL TRANSPARENCY OF GLASS

\footnotetext{
${ }^{40}$ Look at Maison de Verre, chapter 2

${ }^{41}$ Rowe, Colin, and Robert Slutsky. "Transparency: Literal and Phenomenal." Perspecta 8 (1963): 45-54. Print. 50
} 
It can be concluded that spatial perception is just another layer of understanding that is linked with acting on the surroundings. Yet, in order to perceive an object or a space, it must be accessible to us not only in one fixed image, but in phenomenal terms: the series of overlapping images which lead to that goal or object which in themselves are full of possibilities. 


\section{INTERACTIONS WITH MIMESIS}

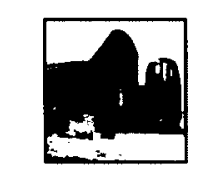

[The Parasite]: the sculptural prosthesis as other to the self-contained

building, replete with its own history and sculptural and social identity, is able

to project a new identity for the building. - Richard Goodwin ${ }^{42}$

\section{Paraticism and Mutualism}

Transparency gives way to understanding the physical and spatial nature of buildings. Graspability does not specifically refer to objects, but also dimensions of space where a specific action dictated by one or more individuals can take place. This negates the widespread assumption that our brains and our bodies interact separately. Consciousness is not centered in the brain at all, but actually functions with the whole body; the body at the same time is embedded in a larger ecology from which it extracts most of its essential stimulation. Important insight of recent neurological research says that the brain in its nonlinear operations does not run by the force of human logic. Mallgrave claims that "the ability to reason, or think logically, is a very late evolutionary phenomena, while the brain, like all biological organisms, has honed its neurological operations over a much longer time, specifically in the

\footnotetext{
${ }^{42}$ Richard Goodwin, Sydney Based Artist_Architect. Web. 09 Jan. 2012. <http://mww.richard-goodwin.com/>.
} 
refinement with which it generates and categorizes its field of neural patterns ${ }^{43}$."

In the twentieth century, architecture turned its attention to how the natural world can be beneficial to the human condition: there are now more efficient mechanical systems that filter air, insulation for more comfortable temperatures, and roofs and walls became greened with the addition of vegetation. The most impressive is our ability to find and mime natural processes to aid the development and design of architecture. Inspired by a spider web, Douglas Cardinal, a Canadian Aboriginal Architect, solved a roof structure of St-Mary's Cathedral in 1967 that was not able to be conceived by the best structural engineers and mathematicians at the time; Antonì Gaudì, developed the structure of the Sagrada Familia by inverting a series of metal chains to let gravity solve the structural problems by providing it form.

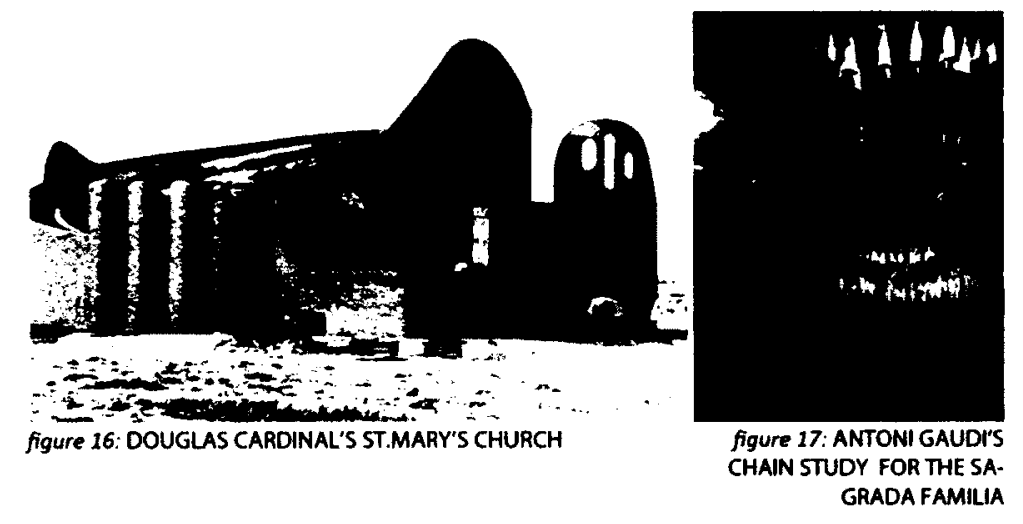

These instances can perhaps be linked to the term biophilia, defined as our "innate tendency to focus on the life like processes." Beyond the admirable greening of architecture, it suggests issues of scale, lighting, views, refuge, order and complexity- what Steven Holl claims in the book Questions of Perception: Phenomenology of Architecture as the "re-assertion of the human

\footnotetext{
${ }^{43}$ Mallgrave. op. cit. p.170-171
} 
body as the locust of experience ${ }^{44}$." As mentioned previously, the brain seeks highly varied environments to satisfy its ever enduring curiosity. It is an attribute shared with all animal life; animals and human alike either seeks objects (food) spaces that are optimal for specific events.

The urban landscape creates ambiguous instances with its leftover spaces, formed by the existing architecture, which can conjure patterns of behaviour into these newly perceived spaces, often hidden in plain sight. These could be unused surfaces, alleys, but most importantly, rooftops. This field of spatial left-overs can best be described as poché. Colin Rowe describes poché in Collage City as "a matrix of major spatial events that exists as residual spaces formed by existing architecture 45 " that frame new possibilities that can be used for individual or group acts. The poché can be understood as any residual space created by existing buildings. It is a concept that specifically denotes public space both within and outside buildings and also akin to block pattern diagrams that record public and private property as simple rectangular blocks. Another explanation for it would be a "figure grounddiagram ${ }^{46 ",}$, but this explanation does not take into account the left-over spaces on rooftops, on, or inside of a building. In any case, the importance of this idea is that it questions the explicit pre-conception of a site. According to Lebbeus Woods, the potential for these left over spaces can also be described as "the authority of individual acts and moments on a continually shifting landscape of acts and authority - the landscape of the free-zone ${ }^{47}$." The free-zone is a

\footnotetext{
${ }^{44}$ Holl, Steven, Juhani Pallasmaa, and Gómez Alberto Pérez. Questions of Perception: Phenomenology of Architecture. San Francisco, CA: William Stout. p. 116. 2006. Print.

${ }^{45}$ Rowe, Colin, and Fred Koetter. Collage City. Cambridge, MA: MIT, 1978. Print.

${ }^{46}$ Rowe, Koetter. ibid

${ }^{47}$ Woods, Lebbeus. Anarchitecture: Architecture Is a Political Act. London: Academy Editions, 1992. Print
} 
space that is not described by any label or metric system, where it is in a "constant state of discovery through additions of individual structures ${ }^{48}$."

In biological terms, the addition to an existing entity is parasitic. A parasite is an organism that lives on or in an organism of another species, known as the host, from the body of which it obtains its nutrients. ${ }^{49} \cdot$ 'Mutualistic' would be a more accurate term to describe the instance where the relationship between species benefit one another, just how the Egyptian Plover helps a crocodile keep parasites off its body, while using those parasites as food for itself.

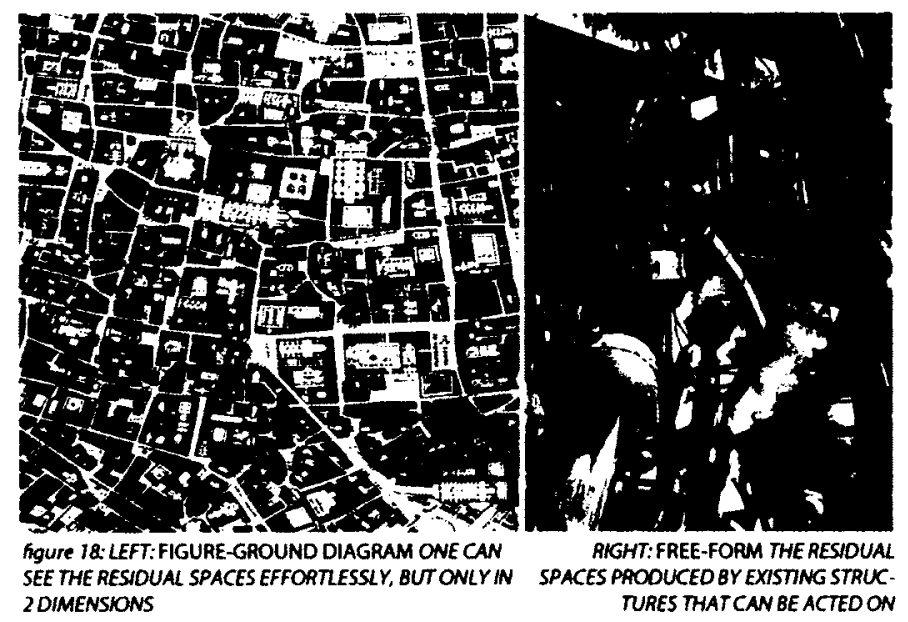

This process, according to psychologist Eleanor J. Gibson, is called the ecological approach. It is based on the assertion that an animal and its environment must be described in relation to one another. An ecological niche implies an animal, and a species implies an econiche. They are co-designed and, therefore, mutually compatible. Through evolution animals have been

\footnotetext{
48 "YouTube - Lebbeus Woods. Experimental Space and Architecture. 2006 1/8." YouTube - Broadcast Yourself. Web. 06 July 2011. <http://www.youtube.com/watch?v=HA1QJGkNz4E>.

49 "Parasite I Define Parasite at Dictionary.com." Dictionary.com / Free Online Dictionary for English Definitions. Web. 04 Mar. 2011. <http://dictionary.reference.com/browse/parasite>

- Parasites are useful in nature but could be deadly for some members of a certain species; In the Amazon, they can take the form of a deadly fungus called Cordyceps Unilateralis, to control a population of ants from growing too large; this controls monopolization of any species of ants.
} 
designed to be able to detect properties of the environment that are relevant to them. After all, their survival depends on doing that. Animal relevant properties of the environment are called affordances. Gibson explains that "the concept of affordance implies that properties of substance and surface enter into invariant combinations especially suited to a given animal supporting its activity. The changing optic array contains information about the environment in reference to the animal as well as information about the location and movements of the animal in reference to the environment. Perceiving something is always a question of perceiving what that something means to the animal. The research task then is to find the best possible description of the environment relative to an animal and also to find the best possible description of the activity of the animal relative to the environment ${ }^{50}$."

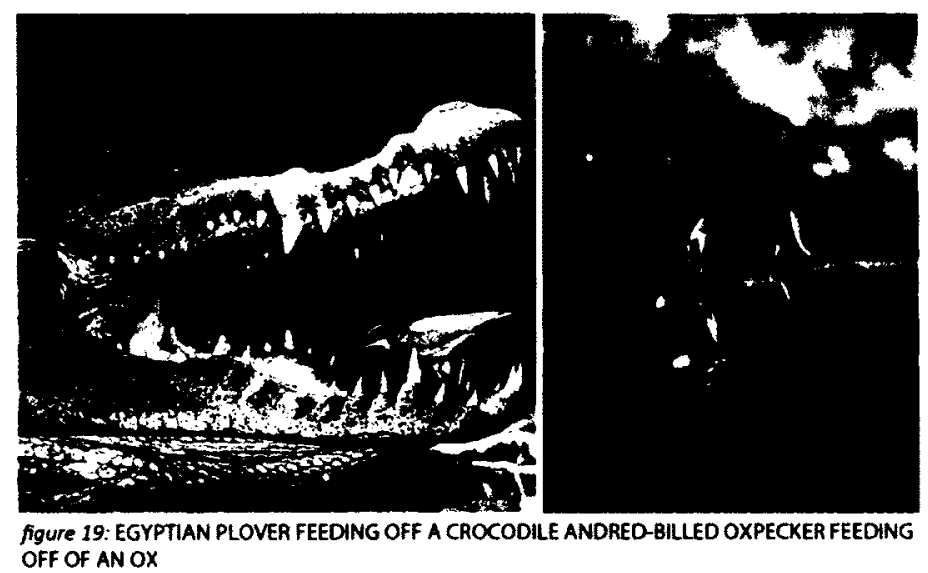

Another concept to describe these events was coined by Paolo Soleri, Architect of Arcosanti, as miniaturization: essentially pertaining to an increasing complexity of behavioural relationships within a given space. ${ }^{51}$ The relationships created are synergistic: the fig tree in the Amazon produced the fig simply because it came to bear its own means of reproduction through its

\footnotetext{
50 Johansson, Jansson, Von Hofsten. op. cit. p.40

51 "Arcosanti : Media : Interview." Arcosanti : Home. Web. 06 Nov. 2011.
} 
seeds. Through evolution, the tree bore the fruit, where the monkey eats it, expels the seeds through its feces; the ground laden bacteria break the nutrients from the feces for the tree's consumption. ${ }^{52}$ Members of certain species ultimately form a new system of interactions which benefit all the species involved. As reflections and extensions to human behaviour, the different architecture can adopt this process of mutualism by accessing the poché and its ambiguous nature by redefining the urban landscape.

One group who did so was Chinese firm MAD architects, who wanted to come up with a solution to re-invigorate the historic neighbourhoods of Beijing. They inserted a bubble like form that contains a stairway and a bathroom into the Hutongs by creating a new access ways to spaces on top of the Siheyuans traditional Chinese dwellings.


figure 21: HUTONG BUBBLE CONNECTNG SPACES

\footnotetext{
${ }^{52}$ Planet Earth. Perf. David Attenborough. BBC, 2006. DVD.
} 
The Hutong Bubbles, as MAD calls them, they are "magnets, attracting new people, activities, and resources to reactivate entire neighbourhoods and its multiple levels. They exist in symbiosis with the old housing. These interventions will become part of Beijing's long history, newly formed membranes within the city's urban tissue ${ }^{53}$."

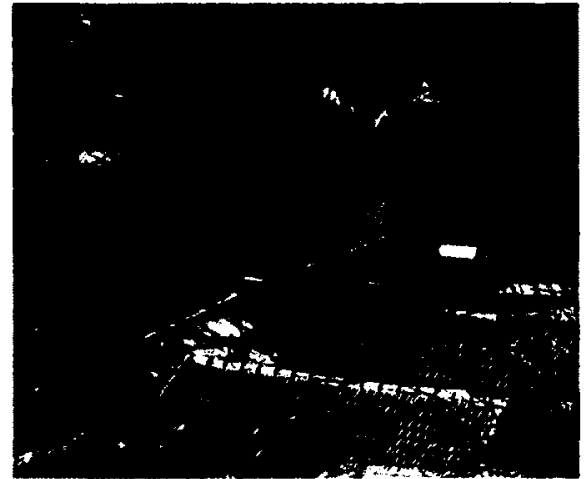

figure 22: HUTONG BUBBLE ROOFTOP VIEW

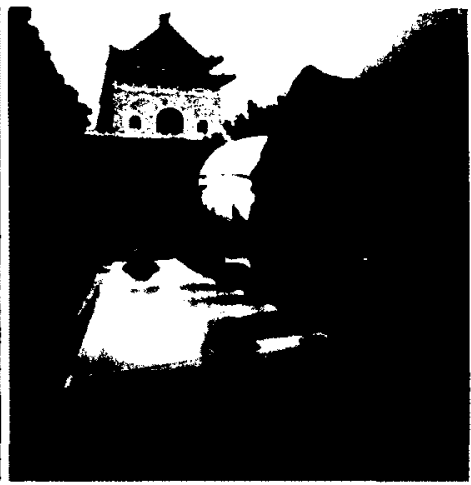

figure 23: HUTONG BUBBLE STREETVIEW

The historic neighbourhoods of Beijing are partly still residential, but according to the Beijing Municipal Administration of Cultural Heritage, there are over 500 historic courtyards preserved in the Cultural and Historical Conservation Areas as important cultural monuments. ${ }^{54}$ Hutong Bubbles produce are miniaturizing the Hutong by complexifying which renders accessibility to unused spaces. ${ }^{55}$

This sort of exchange between society and citizen, at the architectural level, was a phenomenon that occurred naturally within the city of the past. The haptic interaction between architecture and the individual allowed a citizen to understand the value of space, and then had the freedom to personalize it. Today, the easiest thing to do is to build on level ground; a luxury that is gradually deteriorating because of the threat urban sprawl has on the

\footnotetext{
${ }^{53}$ MAD Architects Hutong Bubble 32." A+U Magazine 478 (2010): Print. p. 100

${ }^{54}$ From Hutong to "New-Tong"t. Beijing This Month.

55 "Siheyuan." Wikipedia, the Free Encyclopedia. Web. 06 Nov. 2011.

<http://en.wikipedia.org/wiki/Siheyuan>
} 
ecosystem and biodiversity. ${ }^{56}$ What is missing from our dwellings today are the potential transactions between body, imagination, and environment; to at least some extent every place can be remembered, partly because it is unique, but partly because it has affected our bodies and generated enough associations to hold it in our personal worlds. ${ }^{57}$ These associations can only be strong if there is some action potential. As mentioned before, the mere sight of looking at a branch triggers motor signals that enables one to imagine its graspability, in other words, how one can use it to climb the tree. In that respect, the brain recognizes no difference between the actual action and the perceived action. But once the person actually climbs the tree, it gets reinforced through the brain because new sensory stimuli of touch and smell make it a newly subjective experience which reinforces the perceived action. Then, once you see a branch again, or someone else climbing one, the associative memories from all the sensory stimuli make the experience of watching someone climb much more vivid and carnal. Similarly, this effect can be translated into cities of the past, since the act of building was personal, hence came from the individual and their connection to their city was more personal. In this sense, the relationship individuals had with each other was not just through similar interests, work and family ties, but one that became mutualised through their architecture. This effect can be grounded by Neuroscience, through the discovery of mirror neurons.

\footnotetext{
56 "Biodiversity Urban Sprawl Threatens Biodiversity ." eNotes - Literature Study Guides, Lesson Plans, and More. . N.p., n.d. Web. 21 Apr. 2011. <http://uww.enotes.com/biodiversity-article/urban-sprawl-threatensbiodiversity>.

${ }^{57}$ Bloomer, Kent C., and Charles Willard Moore. Body, Memory, and Architecture. New Haven: Yale UP, 1977. Print.
} 


\section{Mirror Neurons}

Neuroscientist Giacomo Rizolatti discovered in the late 1990's while studying primates, that some neurons fired not only when a monkey performed an action but also when it watched another monkey perform the same action.
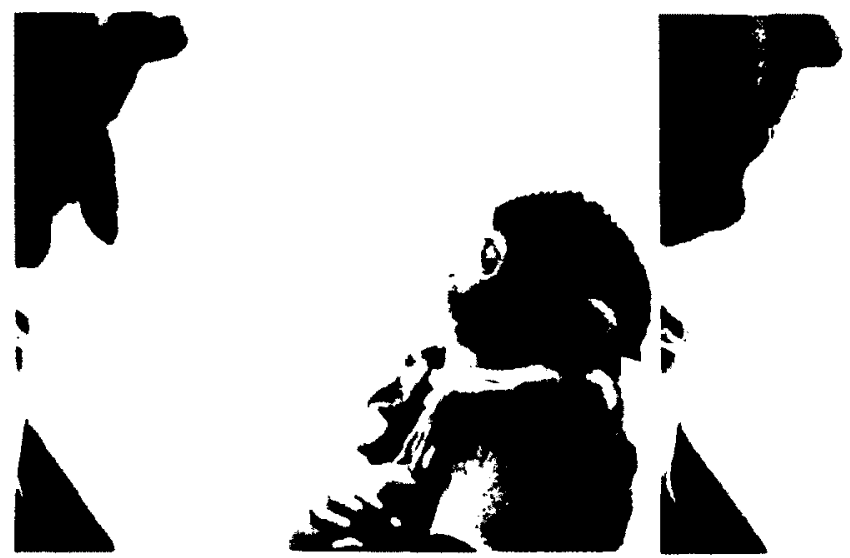

figure 24: MIRROR NEURONS, PREVALENT IN PRIMATES, PUT US IN THE POINT OF VIEW OF THE OTHER

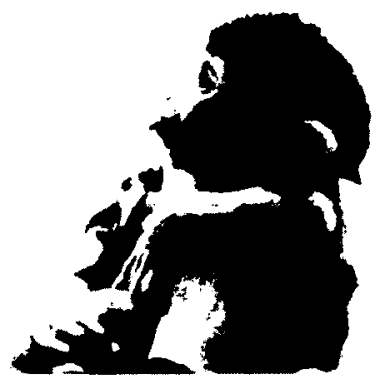

These were called mirror neurons and they were not merely motor-command neurons; they were adopting the other animal's point of view. The neurons were reading the other monkey's mind, figuring out what it was up to. This is an indispensable trait for intensely social creatures like primates. It is as if mirror neurons are nature's own virtual reality simulations of the intentions of other beings.

According to Ramachandran, these neurons have been the vessels that led us to modern civilization. He claims that "consequently, the areas in the human brain where they are present are much more advanced than any other animal, making us unique. These are the areas that allow us to mime what others are doing by also reading the intentions of the mimesis; which have led us to the evolution of language and culture ${ }^{58}$." Mirror neurons might have influenced Ponte Vecchio, the famed commercial bridge that spans the Arno

\footnotetext{
${ }^{58}$ Ramachandran. op. cit.
} 
River of Florence. The building process of the bridge commenced in 1333; first built as a pedestrian bridge, connecting two districts of Florence. At first it was merely an access way, but as time went by, it began to transform. ${ }^{59}$ The farmers, butchers and blacksmiths discovered the possibility for business due to the heavy traffic, so they stationed their banchi (tables) along the sides of the bridge. They understood than within its dimensions, existed possibilities that would be financially beneficial. Ponte Vecchio is thirty meters wide, giving enough room for them to fit on either side of the bridge while the center retained its function as a street. Over time Ponte Vecchio became one of the most important and flourishing trading areas. The Duke of Florence, Cosimo de Medici, eventually evicted the farmers, butchers and blacksmiths because of the stench emanating from their products, allowing only jewellers to be stations on the bridge. These 'lots' then became rentable, but as more time went by, the city sold them. ${ }^{60}$ The merchants who purchased them, built walls and roofs in their allocated lots but the construction continued as more room was needed for business purposes. They built retrobotteghe; the overhanging jetties supported by wooden bracing that jet out from the sides of the bridge. Furthermore, in 1565, Cosimo de Medici commissioned Vasari to build a corridor that rests on top of the shops, from Palazzo Pitti right across the Arno to Palazzo Vecchio. This compilation of events was crystallized into what Ponte Vecchio is today. This emergent type of building process happened through different individual events through diverse periods of time created this

\footnotetext{
${ }^{59}$ Goy, Richard J. Florence: the City and its Architecture. London: Phaidon, 2006. Print. p. 38

${ }^{60}$ Locke, Tim, and Anne Locke. Bridges of the World: an Illustrated History. Basingstoke: AA, 2008. Print. p.88
} 
sensory rich piece of architecture, one that even Adolf Hitler gave specific instructions not to bomb during World War II. ${ }^{61}$

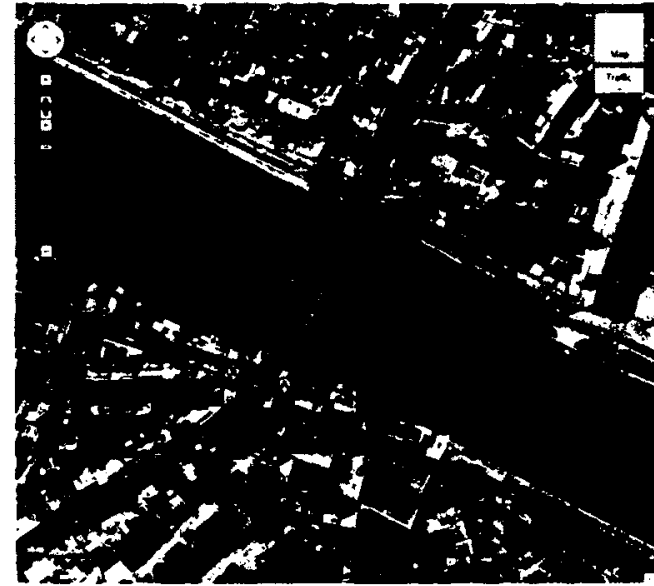

figure 25: PONTE VECCHIO SPANS THE NARROWEST POINT OF THE ARNO RIVER, JOINING TWO DENSE AREAS OF FLORENCE

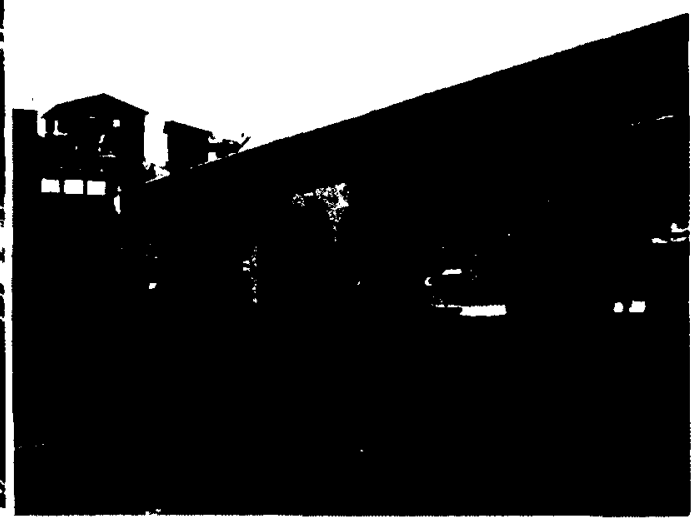

figure 26: THE CONSTRUCTION OF PONTE VECCHIO IS GENERATED THROUGH TIME: (GREEN) THE BRIDGE ITSELF, (PINK) THE RETROBOTTEGHE, (PURPLE) THE VASARI CORRIDOR. THE LAST PARCEL TO BE BUILT

The original Ponte Vecchio, without its shops, was a structure with a monolithic function but it did not mean that other functions did not exist within that space; there is no evidence stating that it was to house additional structures. The act of extracting an individual space amidst a larger one required the locals to focus on the finer dimensions of that space. The instance of scaling down a space to allow possible action is to use the body as a measuring mechanism to understand the general possibilities of the spaces formed with respect to the intention of the architectural intervention, thus with the allowance of proprioception and graspability, Ponte Vecchio was formed. This might be best poetically described by Juhani Pallasmaa:

\footnotetext{
I confront the city with my body; my legs measure the length of the Arcade and the width of the square; my gaze unconsciously projects my body onto the facade of the cathedral, where it roams over the mouldings and contours, sensing the size of recesses and projections; my body weight meets the mass of the cathedral door, and my hand gras $\rho$ s the door pull as I
}

\footnotetext{
${ }^{61}$ Goy. op. cit. p.38
} 
enter the dark void behind. I experience myself in the city, and the city exists

through my embodied experience. The city and my body supplement and

define each other. I dwell in the city and the city dwells in me.

- Juhani Pallasmaa ${ }^{62}$

The transformation of architecture can thus be invigorating to the psyche if it is transformed relative to existing structures. This may be true for buildings as a whole, such as with Ponte Vecchio's shops and the Vasari Corridor; but it also holds true for functional programs as well.

\section{Transformational Architecture}

It does not mean that an emergent structure needs to be additive, as subtracting an existing structure from a larger one is also mutualistic. A project similar to Ponte Vecchio in its construction is the Maison de Verre, built from 1928 to 1932 by Pierre Chareau in collaboration with Bernard Bijvoet. In 1928 Dr. Dalsace and his wife, the clients, intended to demolish the existing eighteenth century building and build from scratch, but the presence of a protected tenant on the second floor obliged clients and architect to envisage another solution. Out of this came the decision to underpin the second floor with steel and to demolish the unoccupied floors beneath, keeping only the existing access staircase. The resulting volume was sufficiently spacious to make room for three new floors. The two contrasting typologies make it seem as if the Maison de Verre was inserted like a Jenga piece, eliminating the first two existing floors.

\footnotetext{
${ }^{62}$ Pallasmaa. op. cit. p.38
} 


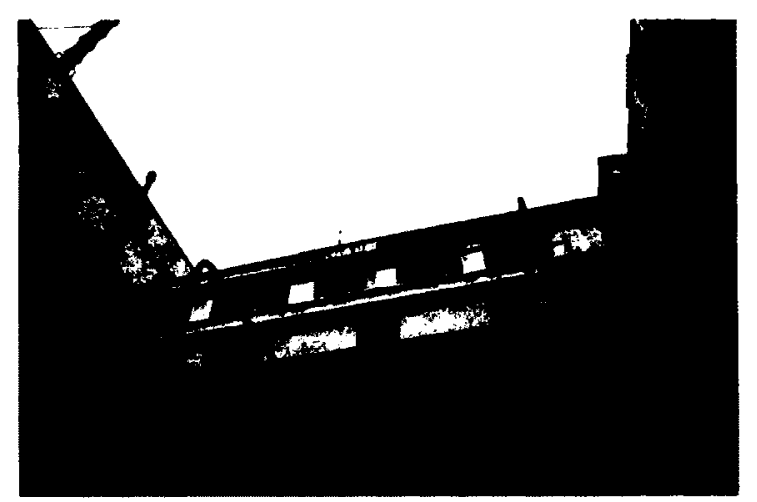

figure 27: THE MAISON DE VERRE WAS INSERTED LIKE A JENGA PIECE SINCE A TENANT ON THE FLOORS ABOVE DID NOT WANT TO MOVE FROM HER APARTMENT

The concept of mobility impregnated nearly all the details of the house,

from sliding or swivelling windows to detachable staircases, from rotating cupboards to pivoting bidets, from sliding partitions to rotating screens. The double functioning elements of the house offer many elements of surprise, or aha moments that range from spatial events to furniture. The ground floor, which was the medicinal practice, is disjointed from the rest of the house; by its lower ceilings, but more specifically by the screen separating the staircase leading up to the second floor living quarters. This element of the staircase, also partially hidden by a glass partition on one side, makes it seem as if it was a painting only given substance by the masters of the house.

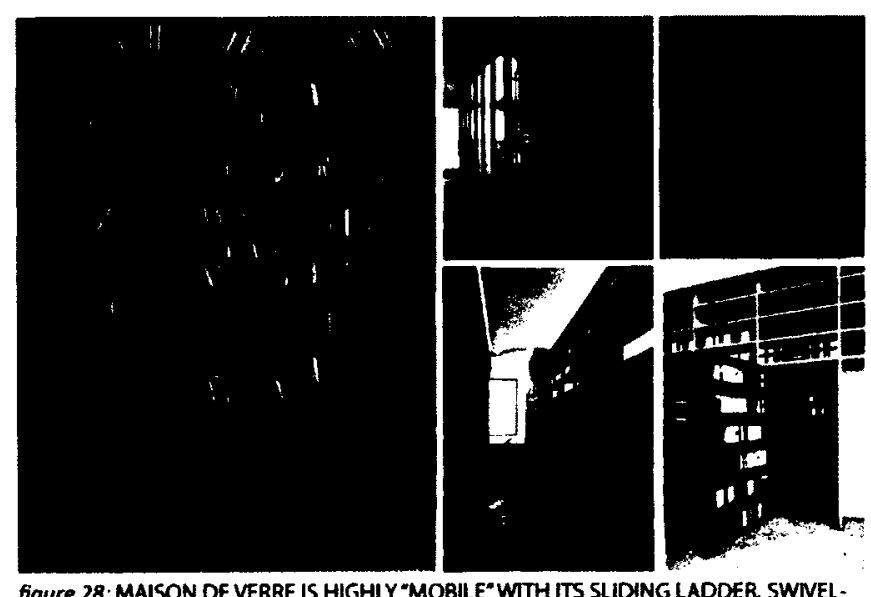


The position of the staircase is also peculiar in respect to the program of the ground floor; it is in the middle of the space but is separated by that glass partition. Once accessed, the stairway leads to a living room; a grand two storey space lit by the glass block facade. Adjacent to it there is a private office for the client, Dr. Dalsace, divided by a sliding metal partition. If the office is not in use, the sliding door opens revealing the office; a one storey space that contrasts the main living room in its scale of privacy. The space acts as an office, but also an interstitial space; beyond it is a row of windows, which contrast the translucent blocks on the opposite end, which reveal a garden. This makes the progression of space fluid, but also ambiguous because of its multiple functions.

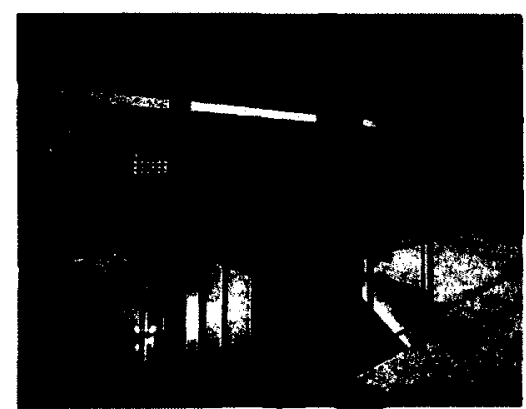

figure 29: MAISON DE VERRE: INTERIOR VIEW

In this respect the Maison de Verre, to the extent that the ultimate motive of each transformation can appear completely variable, is passing from necessity in one case to convenience in the next. From spatial experience to the design of the partitions and furnishings, the Maison offers a rich play of surprise. $^{63}$

The lesson the Maison de Verre gives us is not only its literal transparency but more a phenomenal one; one that is related to its spatial

\footnotetext{
${ }^{63}$ Neumann, Stan, Richard Cowan, and Frederic Compain. "Maison De Verre Documentary."Mvgroup.com Market Developing, marketing Resources and Information. This Website Is for Sale! Web. 19 Nov. 2011. $<$ sttp://www.mvgroup.com>.
} 
ambiguity. This suggests that architectural spaces can be closely related to nature in how they reveal layers of function and meaning. Monolithic functions to spaces are bland and uninteresting because they do not excite our primary emotion of seeking. The same complexity and dynamism of spatial and material relationships that went into the Maison de Verre should be expressed not only in a functional program inside of a building, but externally as well.

\section{Ambiguity}

What seems to make the mind resonate is when two seemingly different notions synthesize, creating the aha moment. The abstraction of this notion is that the particular object in question is neither one thing nor another, but both. In this respect, ambiguity can take on many forms.

Rudolph Arnheim, a German-born author, art/film theorist and perceptual psychologist, gave extensive thought on the notion of ambiguity. He discusses the ambiguous procession of the nave to the transept. The intersection of these two halls creates a space that is part of one and the other. He claims that "this ambiguity in the basic arrangements, (is) the presence of two competing centers. Even the Cupola above this area functions in an ambiguous way, both as an image of the sky and as a canopy for $\operatorname{man}^{64}$." Robert Venturi discusses this issue prominently in his book Complexity and Contradiction in Architecture (1966). He argues that an "architecture which includes varying levels of meaning breeds ambiguity and tension ${ }^{65} . " \mathrm{He}$ is almost focused entirely on the visual considerations of a building as an object of formal composition. Ponte Vecchio is highly ambiguous for that reason, as

\footnotetext{
${ }^{64}$ Eberhard. op.cit.

${ }^{65}$ Venturi, Robert. Complexity and Contradiction in Architecture. New York: Museum of Modern Art, 1977. Print.
} 
its function as a bridge becomes twofold; as a walkway but also as multiple sites for individual shops, each expressed volumetrically. Furthermore, the imposition of the Vasari corridor makes it seem that the shops are supporting it.

Phenomenal transparency is definitely correlated with ambiguity as they both are the result of competing meanings of space. Frank Lloyd Wright, in his Prairie Style, acknowledged than in breaking the box he was forced to come up with a new and ambiguous conception of the wall, one that exalted in disrupting the relationships of inside to outside.

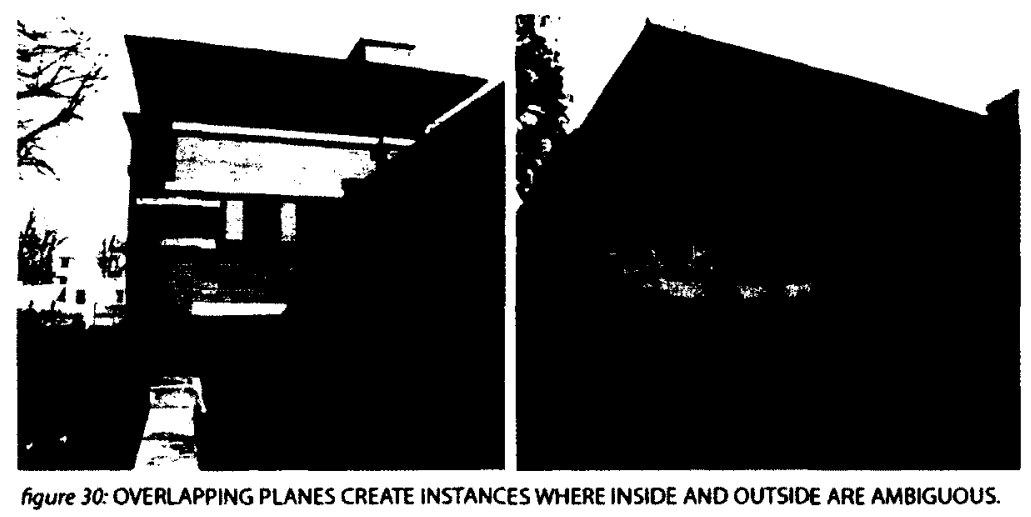

The fragmentation and decomposition, the interpenetration of volumes and the interstitial spaces of the Robie House culminate this process. Wright disengaged the preconceived idea that a wall is an enclosure, rather than its abstracted function as a boundary that acts as a guiding mechanism throughout the architecture. The Robie House recedes from the streetscape in a series of horizontal materials and overlapping planes; this exterior spatial overlap is complemented by an interior that is open to the outside yet sheltered (figure 35). Furthermore, the boundaries in the form of walls intersected by horizontal roof planes that extend beyond the enclosures; defining exterior 
space as well as echoing the flat mid-western landscape that inspired the landscape.

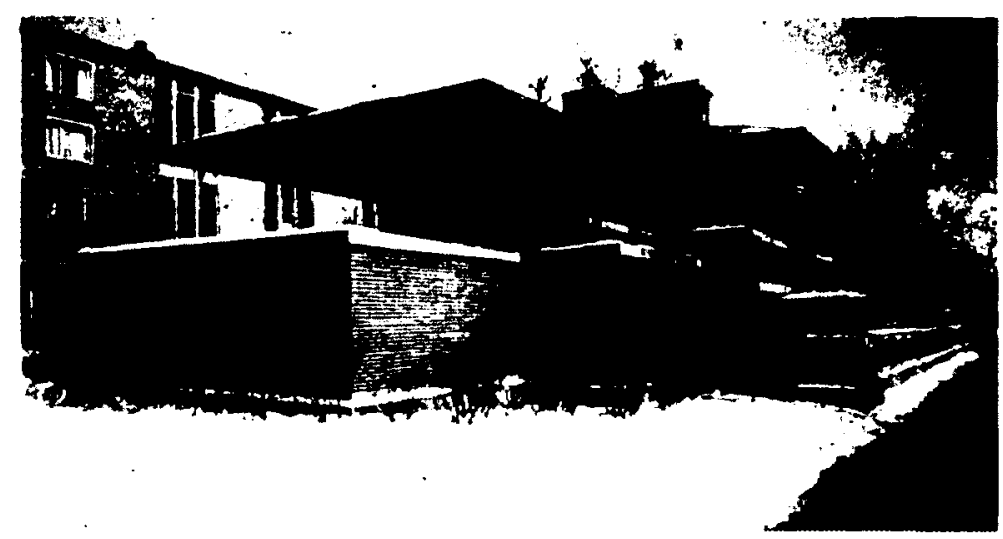

figure 31: THE ROBIE HOUSE RID ITSELF OF THE NOTION OF THE WALL AS AN ENCLOSURE AND REDEFINED IT MORE ABSTRACTLY AS A BOUNDARY MIMICKING THE LANDSCAPE.

A cityscape is full of these ambiguous boundaries; by changing their purpose, one can conceive of adapting behaviour within them. Nature provides an endless amount of ambiguous spaces: in the Amazon Rainforest which is arguably has the most intricate complexity of life, John Terborgh, a conservation biologist, explains how ten species of ant's wren manage to cohabit a single area of the forest while preying on the same kinds of insects. He claims that "one species inhabits an area close to the ground, several more live in the middle tiers of the trees, and another occupies the high canopy. In each of these areas, species forage differently - one middle-tier wren gleans the leaves for insects, another twigs and branches, and so forth, leaving food for the other niches. The tree, which for them is the edifice of their social interactions, is fully occupied without interfering with the integrity of the tree or the other life forms that surround them. They are a synchronised system, where the remainders of space for one species are the opportunity of 
another $^{66}$." Wright's organic architecture can be deemed as mimicry, such as with Gaudi and Cardinal, in its original sense; as stylistic reconfigurations of the natural world. This is, in many ways, a perfect metaphor for architectural creativity. Merlin Donald has hailed mimesis as "the first essential step in human evolution: the bridge between the episodic life of our primate ancestors and the first essential ritualized and symbolic culture of modern humanity ${ }^{67}$." If Architecture is part of the environment, the idea becomes much deeper in respect to neuroscience; just as the different species of animals find their niche in the tree, humans, inadvertently, are always seeking their niche in the environment, provided by the intersecting boundaries presented to them. The New Pathway, as mentioned before, stores subjective experiences that are imbued with different meanings for each person. One person may perceive the same space differently than another, thus architecture is highly behavioural. For example, a stairway with a forty foot hand rail may be hindering to a person with a physical disability, but not for an experienced skateboarder. Lebbeus Woods claims this phenomenon as centricity:

(Centricity) is both a quality and a thing. A city of many centers, an unpredictable number of centers, overlapping, interpenetrating one another. Interfering with one another. Annoying, disturbing, in conflict, one atom with the next. On amplifying one another, building energies together that none could attain alone. A hypothetical city, held together by "laws" - the universal structure of the cycles - unpredictable in form and the infinite possible variations on law and universal structures. Like so many individual human beings - each human, yet different. The only basis for community. - Lebbeus Woods ${ }^{68}$

\footnotetext{
${ }^{66}$ Terborgh, John. Diversity and the Tropical Rain Forest. New York: Scientific American Library, 1992. Print. p. 17

Mallgrave. op.cit. p.186-187

${ }^{68}$ Woods. Anarchitecture. op.cit.
} 
Spatial and architectonic transparency gave rise to a quality of architecture as ever changing, overlapping instances of personalized architecture. The ambiguity of functions personalizes the perceived space to influence individual action since we are constantly "seeking." Our nature as creative problem solvers deciphers the different ways in which we can perceive the same space; it now holds multiple functions; ones that are pre-existing (the bridge of Ponte Vecchio) and ones that are interpreted by the observer (the shops on Ponte Vecchio, and the Vasari Corridor). 


\section{SHEDDING THE BIASES}

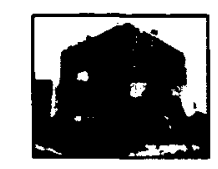

\section{Sharing Space}

How does the street interact with the architecture? This is often questioned when designing a building. This in essence singles out the street and buildings as mere objects. Large scale buildings are often extrusions of their footprint which invites only those for whom it was built for. They do not offer any form of perceptual invitation in their space. How does architecture, interdependent with its program, extend the street so that the distinction between the two are blurred?

A building which quite literally extends the street through it is the TEK Cube by BIG architects, a firm based in Denmark. The BIG TEK Cube is a proposal for a building in which transforms the horizontal ground plane of the street into a vertical one. 


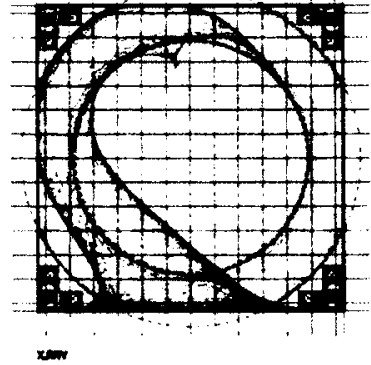

nom

figure 32: VIEWS OF THE PROCESSION OF SPACE FROM THE STREET TO THE ROOFTOP.

Inside and outside spaces are blurred as the pedestrian realm of street is

transformed by the building into a corridor which is entered through a large

circular opening, leading up to the rooftop garden.

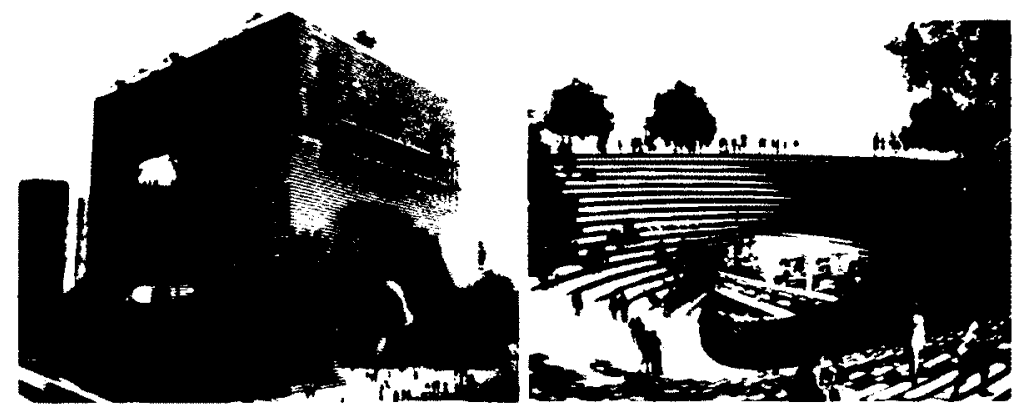

figure 33: THE BIG TEK CUBE EXTENDS THE STREET THROUGH A VOID IN THE BUILDING, ACTING AS A ONTINUATION OF THE PUBLIC REALM

On the way there are hotels, shops, showrooms, galleries, offices, restaurants and stores which allow for people to do as they please along the way. In other words, the building's architecture seems to be designed directly for the public realm (anywhere where the public has access, e.g. the street), while any remaining spaces are the private realm of the building. The street is extended through the building itself ${ }^{69}$. The reason this is significant is because the function of the street can be redesigned accordingly to aesthetically please the

\footnotetext{
${ }^{69}$ Yoneda, Yuka. "BIG Unveils Gigantic Cube Building with a Rooftop Park Ted Cube Building by BIG Architects - Inhabitat - Green Design Will Save the World." Green Design Will save the World | Inhabitat. 8 Oct. 2010. Web. 03 Mar. 2011. <http://inhabitat.com/big-unveils-gigantic-cube-building-with-a-rooftoppark/ted-cube-building/?extend $=1>$.
} 
pedestrian in large scale architecture. The highly rational buildings of Modernism, as well as the reductionist buildings of post-modernism, does not fully engage the human being since they are unaware of a very important consideration: humans are complex systems themselves, as everyone has an inner drive. People have the ability to create their own personalized worlds by their freedom of choice.

I'm saying the jumbo jet is a very complicated piece of equipment. A great piece of equipment, but it's complicated, not complex. The canary is a complex phenomenon, entity. Why? Because the canary has an inner motivation. It's driven by its own inner genetic guidance. - Paolo Soleri ${ }^{70}$

\title{
The Individual Act
}

\begin{abstract}
The architect who designs building non types - the freespaces of unknown purpose or meaning - inverts the pyramid and creates new ones. Each inhabitant is an apex, placed on end, a point of personal origin. Each pyramid expands into a void of time, seeking its base, its terminus that would render the volume of experience, resisting completion. In the indeterminate darkness of the void, many pyramids interpenetrate and dissolve, one into hers. They form a flux, a matrix of indeterminacy, an inconsistent pattern, a city of unknown origin and destiny, a politics not of being, but of becoming. Ontogenetics." ${ }^{71}$ - Lebbeus Woods
\end{abstract}

Freedom of choice implies that the individual can exert some control over his physical setting. Individuals not only lay claim to privacy or themselves as corporeal objects, but for the things they own, the spaces they occupy, and their so-called personal effects. The personal pronoun my in the sense of $m y$

\footnotetext{
70 "Arcosanti : Media : Interview." Arcosanti: Home. Web. 06 Nov. 2011.

${ }^{71}$ Woods. Anarchitecture. op.cit p.8
} 
room, my desk, my neighbourhood, my sheet, my file, etc., implies more than legal or normative ownership. Proshansky claims that these objects, spaces and places are "extensions of the individual self - they may be elements of selfidentity and in this sense, the individual and only the individual can determine who besides himself - if anyone at all - will use them, change them, or even view them ${ }^{72}$."

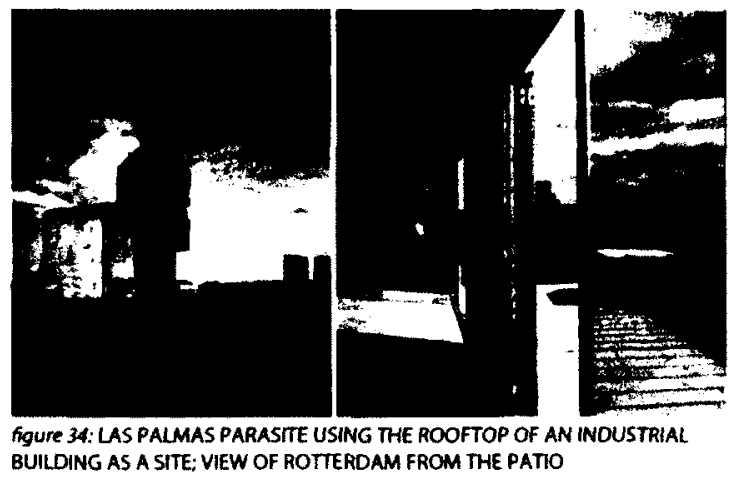

An instance of such an individual act has been experimented by Korteknie Stuhlmacher architects on an industrial building in Rotterdam. The Parasite, as it is called, attaches itself to the abandoned warehouse, which is used as an anchor, and acts as its main structural support. Services like water supply, sewage and the electric installation had been linked to the existing warehouse building. The structure was built using pre-fabricated wood panels designed to be assembled with ease, and simply craned into place ${ }^{73}$.

\footnotetext{
${ }^{72}$ Proshansky. op. cit.

${ }^{73}$ Orangemenace, "Parasite Architecture." AMNP. Apr.-May 2007. Web. 04 Mar. 2011.

$<h t t p: / / a r c h i t e c t u r e$. myninjaplease.com/?p=944>. 21
} 


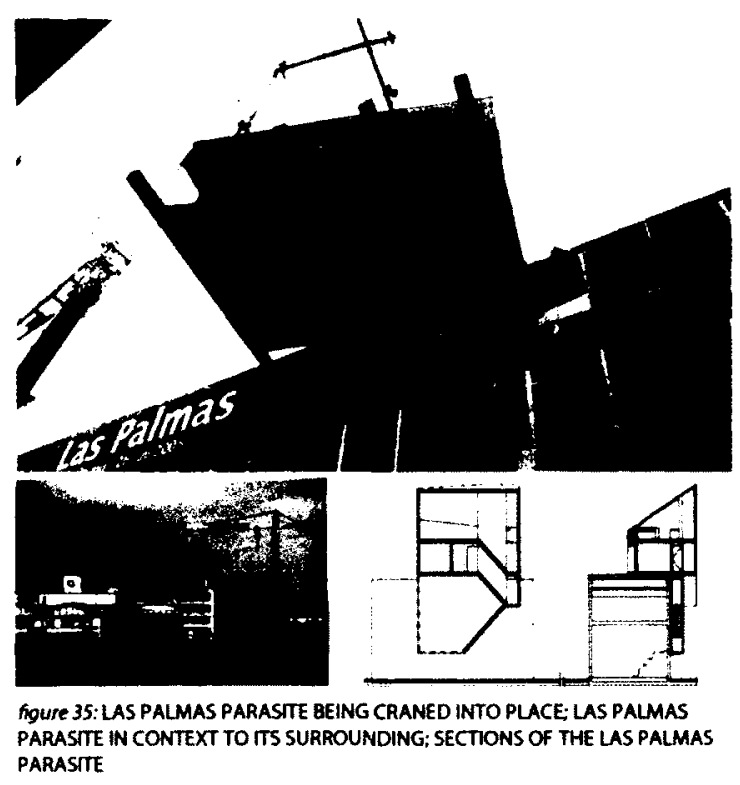

In this sense who designs, who builds, who owns, who inhabits? The architect who designs building types is a pyramid builder, who follows the hidden forms already inscribed by those expressing and dominating others, and who benefits by conventions, conformity, and all adherences to the rules of the normative. The inhabitants are on the lowest spectrum of the game. They receive what has been given; yet bear all the weight of the superstructure above. Who are the inhabitants? All architects are deeply involved in their work with the political, whether they or not admit it to others, or to themselves. Most architects in this highly commercial era, who accept commissions and clients that affect public life, are in fact committed to supporting the existing structure of authority as embodied in institutions of commerce and of its supporting political systems. Only a handful of work against it because they believe it is regressive in terms of architecture or society, or both. It is no wonder that the majority of architects avoid the political implications of their work. Woods 
claims "they become executors of a physical and social order designed by those institutions presently holding political authority and power ${ }^{74}$."

The form of the city is determined primarily by thousands of private decisions to construct buildings, within a framework of public infrastructure and regulations administered by the city, state and federal governments. City planning actions can have enormous impacts on land values. From the point of view of land economics, "the city is an enormous playing field on which thousands of competitors struggle to capture value by constructing or trading land and buildings ${ }^{75}$." The goal of city planning is to intervene (through zoning, which is not planning, but implementation of rules) in this game in order to protect widely shared public values such as health, safety, environmental quality, social equality, and aesthetics. Lynch discusses that "perhaps this is so because of the lack of control individuals have in respect to the cultural development of the city, which seems to breed detachment ${ }^{76}$. The information age, brought forth by the internet, only reinforces this problem:

\footnotetext{
"As we cultivate lives of distraction, we are losing our capacity to create and preserve wisdom and slipping towards a time of ignorance that is paradoxically born amid an abundance of information and connectivity. Our tools transport us, our inventions are impressive, but our sense of perspective and shared vision shrivel." - Maggie Jackson- Distracted- (2008)
}

But it seems that when outside of the socio-economic norms, such as squatters, respond to problems in creative ways. Some squatters in Hong Kong, having no place to go in such a dense environment, resorted to the only available spaces: on rooftops. Some of these squatters formed communities

\footnotetext{
${ }^{74}$ Woods. Anarchitecture. op. cit. p.8

${ }^{75}$ Woods. Ibid. p.8

${ }^{76}$ Lynch. op. cit.
} 
with intricate labyrinthine passages formed by personalized huts, using scrap sheet metal, wood, tarps and other various materials.

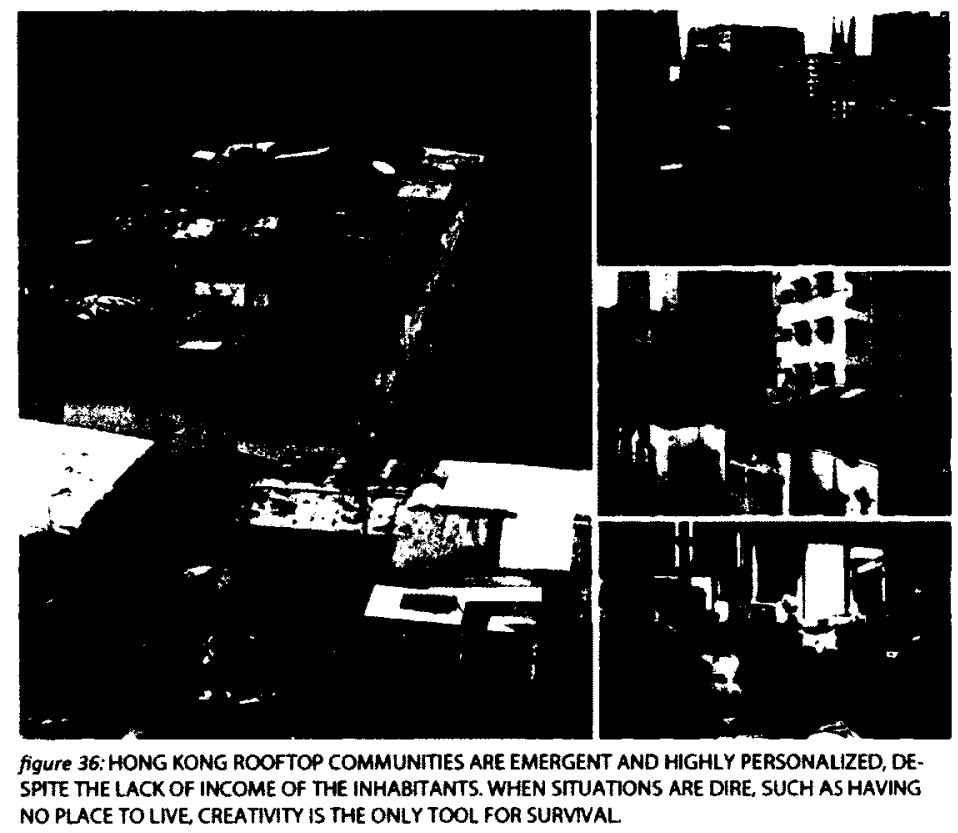

Some still have to pay rent, but it is minimal, since the building was already complete once they settled in. Some of them attached their units to the services of the buildings, while some landlords are unaware of it. A lot of these people had no other choice, but some of the inhabitants literally chose to live in these locations, while others see the inherent benefits. For example, one man decorates his unit with harmonized colour palettes, simulated stained glass stick-ons, and potted greenery rotated between different locations to maximize sunlight ${ }^{77}$. He prefers to live on the rooftop than his previous apartment convenient, cheap (only about $75 \$ \mathrm{CAD} /$ Month), better air circulation, and more sunlight. Another person claims that his friends helped him renovate his rooftop flat. What used to be a bedroom is now a storage room accessed by a ladder through a small opening. For the purchasing price of roughly $\$ 10,500$

\footnotetext{
${ }^{77}$ Wu, Rufina, Stefan Canham, and Ernest Chui. Portraits from Above: Hong Kong's Informal Rooftop Communities. [Berlin]: Peperoni, 2008. Print.
} 
CAD (which is one tenth the price of a comparable sized regular flat in the same district), he is able to live rent-free for as long as the government authorities do not evict him $^{78}$. The passage through the adjacent stair core has been blocked, placing his unit at the end of a dead-end corridor. Another married couple and their teenage son live in a rooftop unit, where the teenage son prefers his family's present home to previous regular flats for one simple reason - he has his own private bedroom ${ }^{79}$. This unit boasts a wall separating the washroom from the kitchen. A tree emerges through the seemingly infertile concrete floor of the outdoor patio, which is also the roof of the water tank below ${ }^{80}$. For the passerby, this offers a diverse visual experience; one that is stimulating, ambiguous and picturesque. As with Ponte Vecchio, the Hutong Bubble and Las Palmas Parasite, the instance of scaling down space through the poché, can be explained by a contractive feeling. Robert Vischer claims that in looking at a tiny seashell on the beach, for instance, "we compress ourselves into the small intricate object. In viewing a large building, by contrast, we experience an expansive feeling ${ }^{81}$." The point of all of this is that our empathic relationship with an object (with space, and the behaviours associated with them) is at heart physiognomic, or emotional.

We a have physiognomic understanding of the world because we have bodies, and this relationship inspires empathy when we read our emotions and our personalities into the objects of the world. In the case of the Hong Kong rooftop villages, their typology is completely contrasted by the flat planes of the apartment buildings they rest on. It is visually stimulating at the very least; but they project, perhaps through their materiality and visual

\footnotetext{
${ }^{78}$ Wu, Canham, Chui. Ibid

${ }^{79}$ Wu, Canham, Chui. Ibid.

${ }^{80} \mathrm{Wu}$, Canham, Chui. Ibid.

${ }^{81}$ Mallgrave. op. cit. p.78-80
} 
distinction, that they are individual acts. Vischer claims that "forms such as these are pleasing when they intensify a human's biological life, when they mirror, or bring something to the complexity of the viewer's own neurological life ${ }^{82}$." The squatters used their sense of proprioception and graspability to extract a dwelling from an existing space. They acted on the rooftop as if it was a site, an ever-present tabula rasa. Soleri finds these kind of situations to be frugal, where he explains that "to be frugal means to find, if you might call happiness, not from the holding up on ideas and holding on things of the aesthetic, so it's not that you renounce when you become frugal, you're opening up yourself more to more of the interior values that are more fundamental for the human animal. So it's not only necessity, it's a necessity which almost automatically becomes a vision." ${ }^{183}$

Again, if half of our neural circuits are formed after birth, then it stands to reason that the more we experience people, the world, and its architecture, the more we contemplate, discuss, read, practice, and enmesh ourselves in the nuances of our fields of activity - the richer and more efficient our mental processing and associative networks will become. Juhani Pallasmaa expressed this idea well when he pointed out that design is not a unique exercise in problem-solving (and not unique to architects, but to everyone), but "creative work of all kinds [...], is a matter of working on one's own selfunderstanding and life experience as much as on the concrete object of work $^{84}$."

What neuroscience and the broader field of cognitive investigations are once reminding us that we are still creatures imbued not only with aspirations,

\footnotetext{
${ }^{82}$ Mallgrave. op. cit. p.78-80

83 "Arcosanti : Media: Interview." Arcosanti : Home. Web. 06 Nov. 2011.

${ }^{84}$ Mallgrave. op. cit. p. $172-173$
} 
but also with vestigial biological needs. Mallgrave claims that "if culture is the social edifice constructed on the footings of this heritage, it must therefore respect the primal nature of our existence ${ }^{85 ",}$, thus buildings should be designed and built in such way that allows people to act on them.

Phenomenologically speaking, the fabric of the city should be complexified. Complexity is described as systems having the some processes throughout differing scales, as seen with the Maison de Verre, in its relationship to the existing building and as well as with Ponte Vecchio; they both treated the existing structures as sites. Complex systems have a lack of probable behaviour, where certain thresholds affect behaviours in the system. The interaction of the components in the system is not dictated by a higher power. The attributes listed should also manifest at different scales. For this to happen, building cannot be done conventionally since the building would be dictated by a higher power. People need to share built spaces that are unused by one but can present themselves as a potential intervention to another. It is the individual act, the component, which generates the form. The built environment could become more playful and experimental if people can choose where they want to build their dwellings.

${ }^{85}$ Mallgrave. Ibid. p. 206 


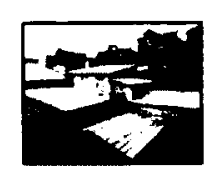

\section{Extension of the Street}

The snapshots that we perceive from our environment come together into a fluid visual scene. This perceptual collage does not occur in two dimensions, as the modern city is normally designed; rather the world is experienced and acted on in three dimensions; left, right, up, down and their spatial combinations. Humans are hard-wired to do so.

The street is the city's centre. This is not a geometric point in a given area, but rather the common space that every person uses to get around; contains every truck to relay goods to business; holds services that heat, cool and provide our homes and shops with water and electricity. It is has a large importance and is the lifeline of society; yet it is designed for the automobile. Flat, smooth and large streets are ideal as the car has become the centre of importance. 
I do not wish to downgrade the importance of the car, but it should not trump the most important aspect of society: the human being. The human being has been cast aside onto sidewalks, and most of our family, friends, centres for entertainment, sports facilities, etc. have been moved far away, where a vehicle of some sort is needed to reach them. I think that buildings, such as the TEK Cube by BIG Architects, should provide new pedestrian realms that have otherwise gone extinct. Buildings, in this sense, can become environments, and can connect with themselves in three dimensions, where the car cannot go. We have eroded the street and self-appointed the car as its new master. Buildings can open themselves up and share their spaces with the pedestrian.

The first step is then to extend the street into the building. I will take Ottawa's Byward Market as a case study since it is well known to me. I have lived in Ottawa for almost 16 years.

\section{The Site}

The Byward Market is one of the busiest neighbourhoods in all of Ottawa. It is located northeast of the capital's downtown core and a few hundred meters from the Parliament Buildings. The Byward Market typically refers to the area between the Ottawa River and Rideau Street from north to south, with the east-west boundaries being King Edward Avenue and Lower Town. This small area serves as one of Ottawa's most popular commercial sectors, and is the centre of much of Ottawa's nightlife. 


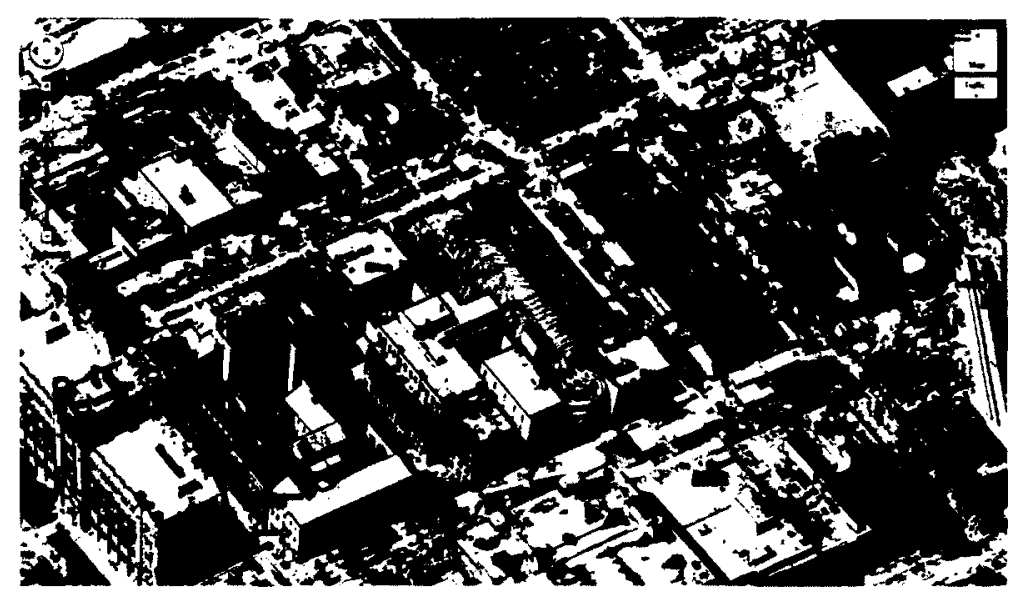

figure 37: PARKING GARAGE ACTS AS AN EXTENSION OF THE BYWARD MARKET

It attracts a wide cross-section of residents. From families to students to young professionals, every demographic represented.' As of the 2006 census, Byward Market had 4,525 residents. The population has a significant proportion of young adults and seniors, as well as very few children and youth compared to the city average (almost $25 \%$ ). The distribution across age groups was as follows: $2.4 \%$ were children under 9 years of age, $3.2 \%$ were youth aged 10 to $19,22.4 \%$ were young adults aged 20 to $39,36.9 \%$ were middle aged adults aged 40 to 69 , and $16.4 \%$ were seniors aged 70 to $89 . "$

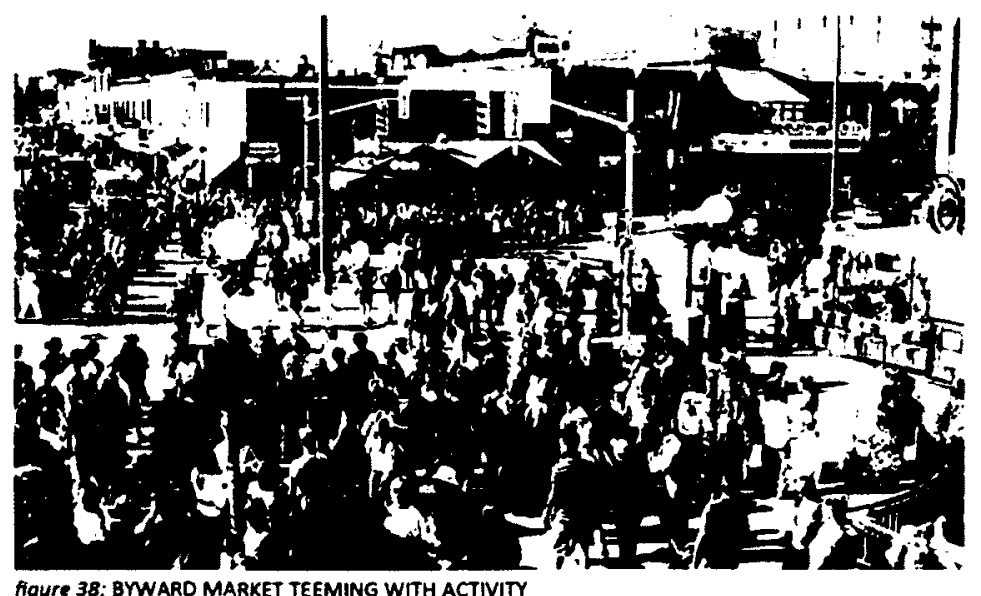


The site is usually congested, even during winter months, especially where the outdoor markets lie. The first step is to offer more space to the local merchants. The problem is that there is not much space left over, as when the market is active, it is hard to even walk.

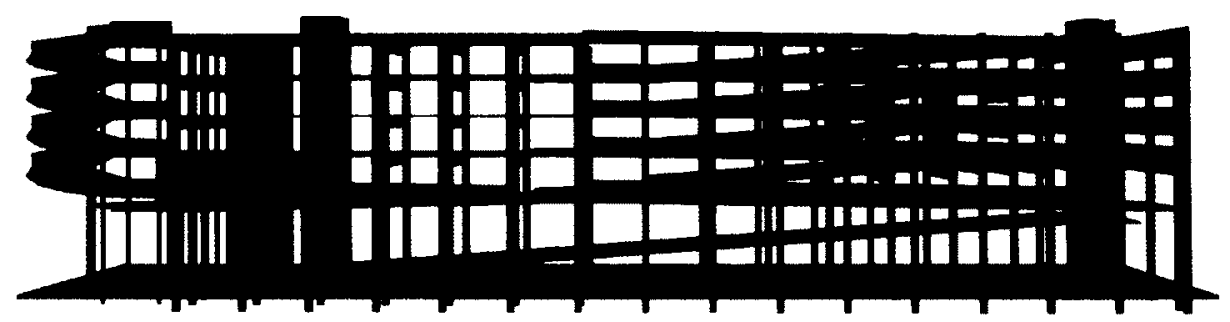

figure 39 - LONGITUDINAL SECTION OF PARKING GARAGE

There is a parking garage that connects George and York street. The parking garage could act as a convenient structure to extend the outdoor market. It has ramped levels which connect the spaces in the structure into one fluid experience. It can also house four times the number merchants of the same footprint with its multiple levels. This will offer a majority of them shelter from the elements, but also is the first move into extending the street into a pedestrian, three dimensional one. It transforms into ambiguous structure; the typology of the building makes reference to its original function, but its new use changes its perceived quality. They can rent out the space as they traditionally do on the street or purchase a lot (within the dimensions of their behavioural space) 
(a)

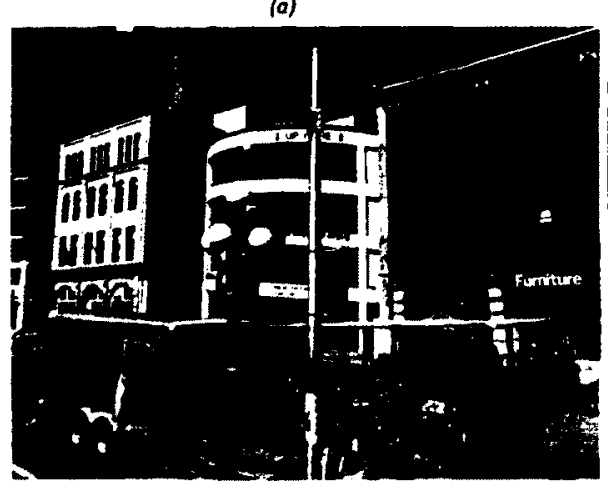

figure 4a- PARKING GARAGE ON GEORGE STREET (a) AND YORK STREET (b)

(b)

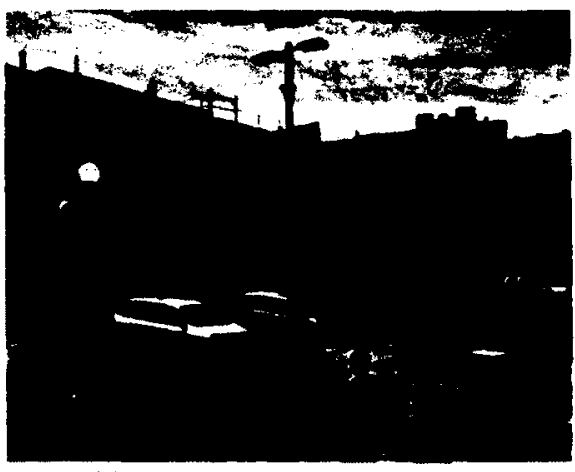

But before this can happen, the parking structure must give, architecturally, a haptic response to the passerby. It must invite, physically, by pulling people in.

\section{Structure}

The George Street façade elicits a strong presence as the function of the curved, ramped passageway is felt with the body. Its slope and curve indicate that it is indeed a path or circulation, entering and exiting the main body of the structure. Phenomenal transparency that can be perceived is blocked by the concrete guard rails throughout the building. Replacing them with glass will widen the gaps between floors so that interior space can be perceived from the outside. Since transparency of motion and function elicit an empathetic response to viewers the stairwells, one located at each end of the parking structure, and the elevator, located near the George street entrance, are stripped of their concrete shells and replaced by Glu-lam and glass. 


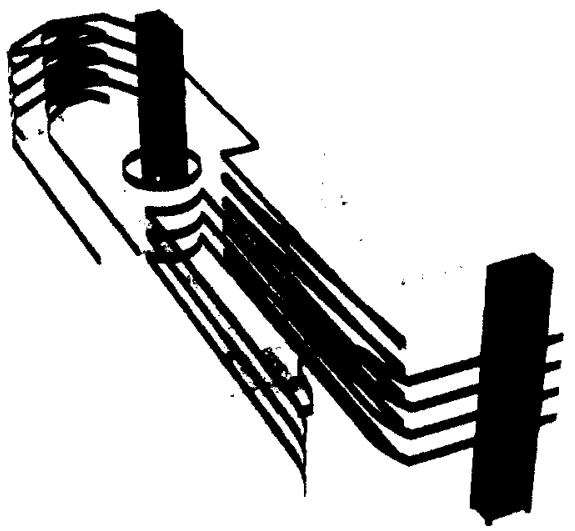

The York Street façade takes on a different form. Its planar surface mimics the streetscape but must be broken into one that suggests the pedestrian to enter. The concrete beams and columns, along with the floor slabs are cut into an undulating form (that starts and ends back onto the planar streetscape, which creates a void). This void breaks the linear street, and calls the pedestrian to enter. Furthermore the second, third and fourth floor slabs are removed to create a grand hall, which by differentiation breaks the expectation one has of the surrounding buildings, projected by windows their every levels. 


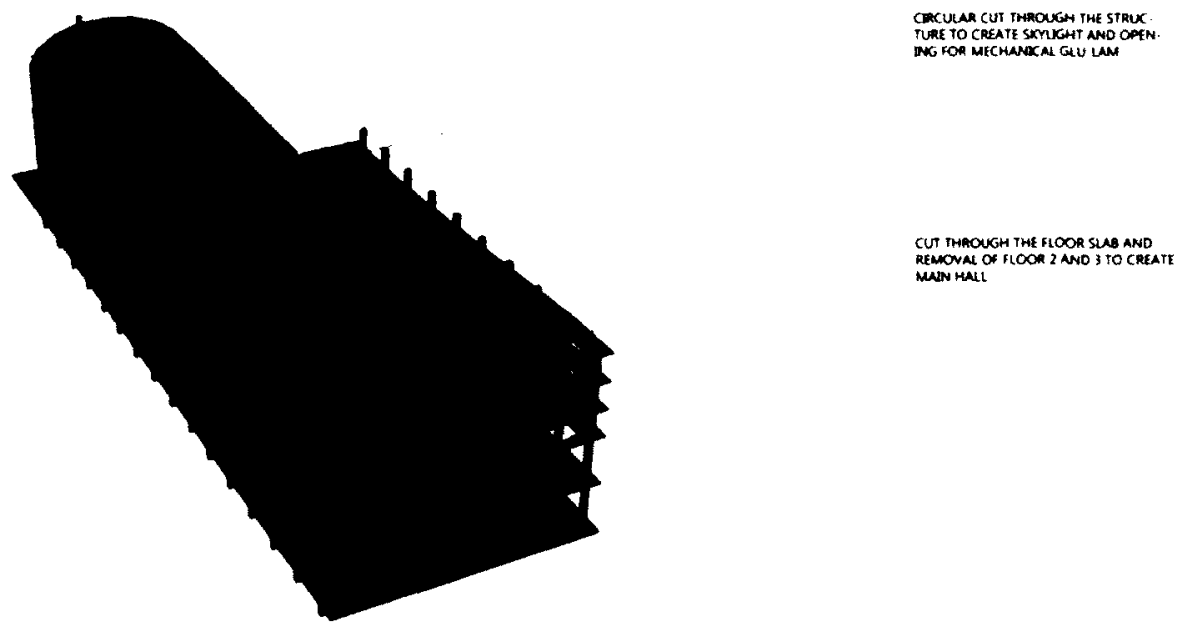

Supporting the concrete is a Glu-lam structure. Glu-Lam has been proven to be strong, lightweight, easily workable, can be machined into virtually any shape, and most importantly, it is resistant to various weather conditions and pests ${ }^{\text {iii }}$ and can be added onto continuously.

Figure 43: GLU-LAM STRUCTURE SUPPORTING SLABS ANO CONCRETE STRUCTURE

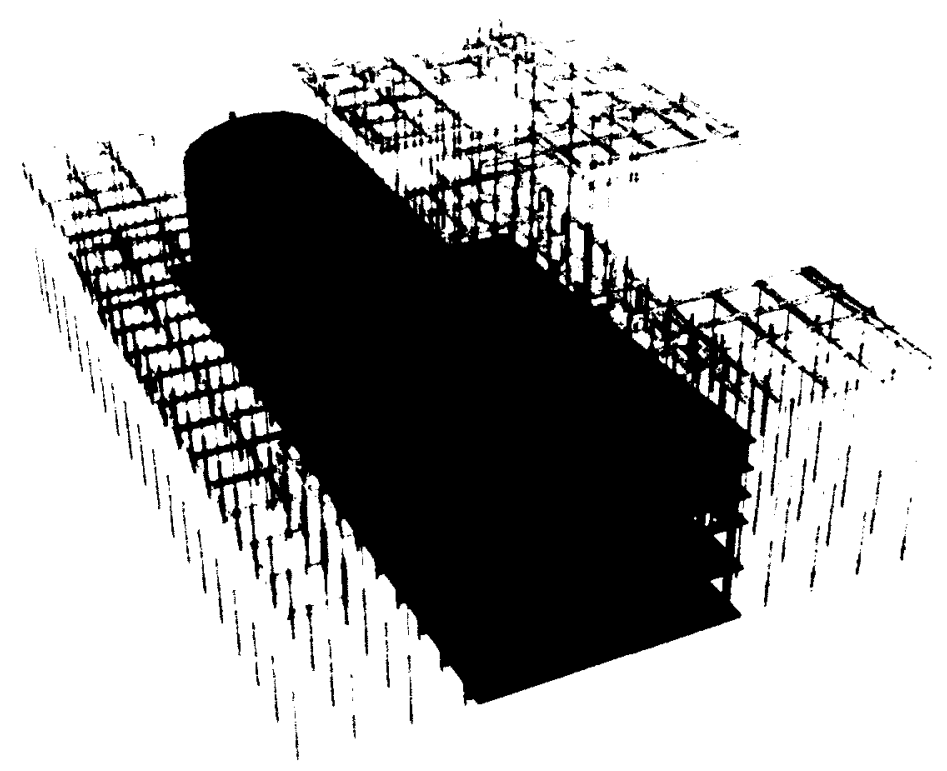

PUMABSG NNO ELECTRCAL FED

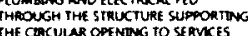

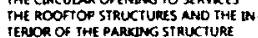

GIU LAM STRUCTURE SUPPORTED BY CAPE GHU LAM STRUCTURE REDFFORCES THE
CUT CONCRES SLABS ANO STRUCTURE 
The services will come from the circular Glu-lam structure located at the centre of the structure which cuts through all the floor slabs, to reach the mechanical room at the basement level.

The parking structure now becomes a public space of its own that disperses pedestrians through multiple levels. Once at the top, the rooftops of the adjacent buildings become perceived. This means that they are now understood with the body as space that can be explored and occupied; a new ground plane. This is what the poché exemplifies: a field of major spatial events created by existing buildings. These spatial events vary in size and shape, and located anywhere in three dimensions. The roofscape can be accessed if the structural integrity of the existing buildings below is reinforced. Steel posts can be laid out inside the shops since they are not exposed to the elements. These steel posts will support the external structure made out of wood Glu-Lam that will mimic the varying levels of the adjacent roofs.

figure 44: STEEL POSTS PLACED IN EXISTING SHOPS IO SUPPORT THE GLU.LAM STRUCTURE

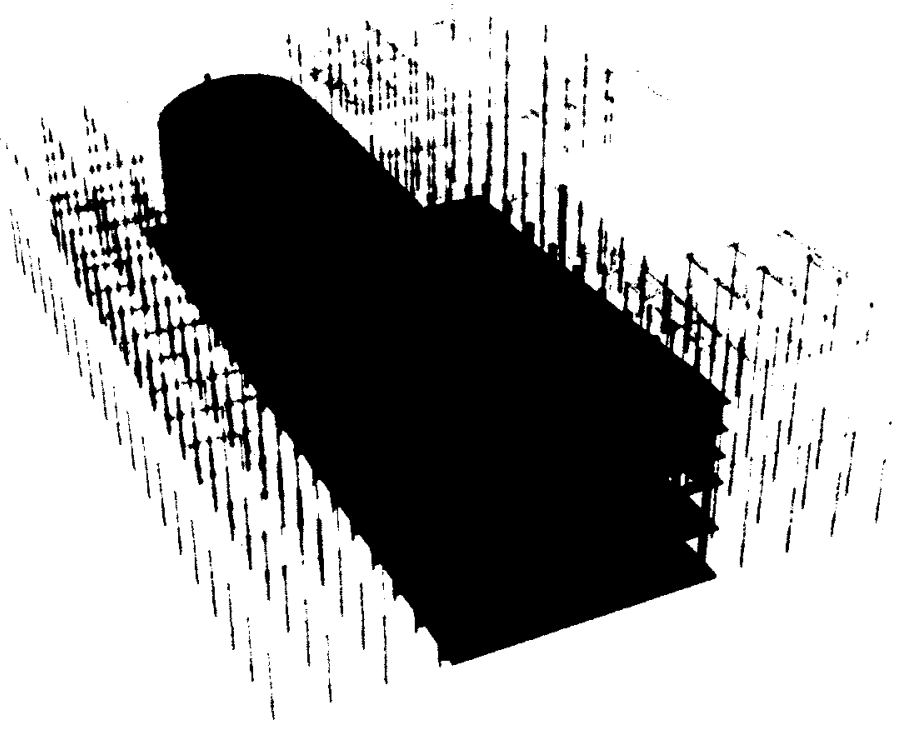


Furthermore, the Glu-lam will also house the plumbing, electrical and water mains that would service the individual acts. The plumbing and electrical mains will be provided by wooden conduits throughout the parking structure. The conduits that provide the plumbing, electrical and water are housed in rectangular hollow tubes. The tubes are insulated to prevent the water from freezing, and they have a door on the underside face which can be accessed by the trades to replace or repair any faulty piping.

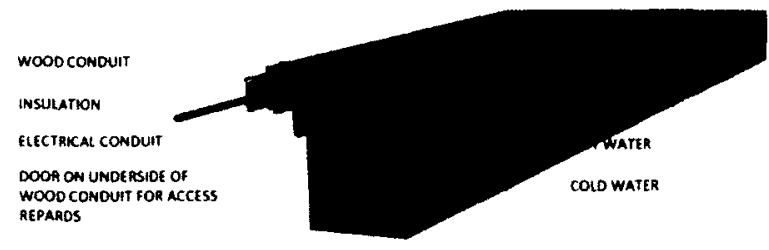

figure 45: WOOD CONDUITS WHICH PROVIDE SERVICES

The new parking structure spills onto the rooftops by continuous ramps that start on the top level of the parking structure.

figure 46: RAMPS LEADING TO THE ROOFTOPS

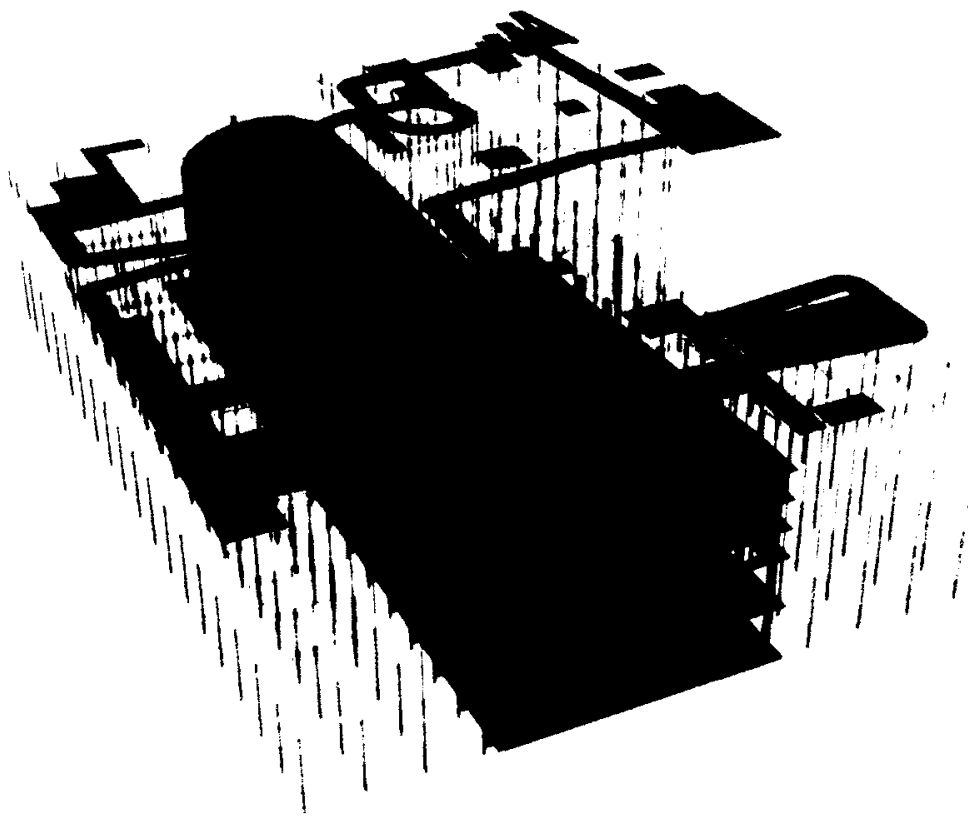
RAMPS THAT LEAO TO TME VARTINC
LEVEIS OF ROOFTOPS 
The ramps join what used to be separate spatial fields into one; creating newly accessible spaces that can house sites for individual acts, made functional by the services provided by the Glu-lam structure.

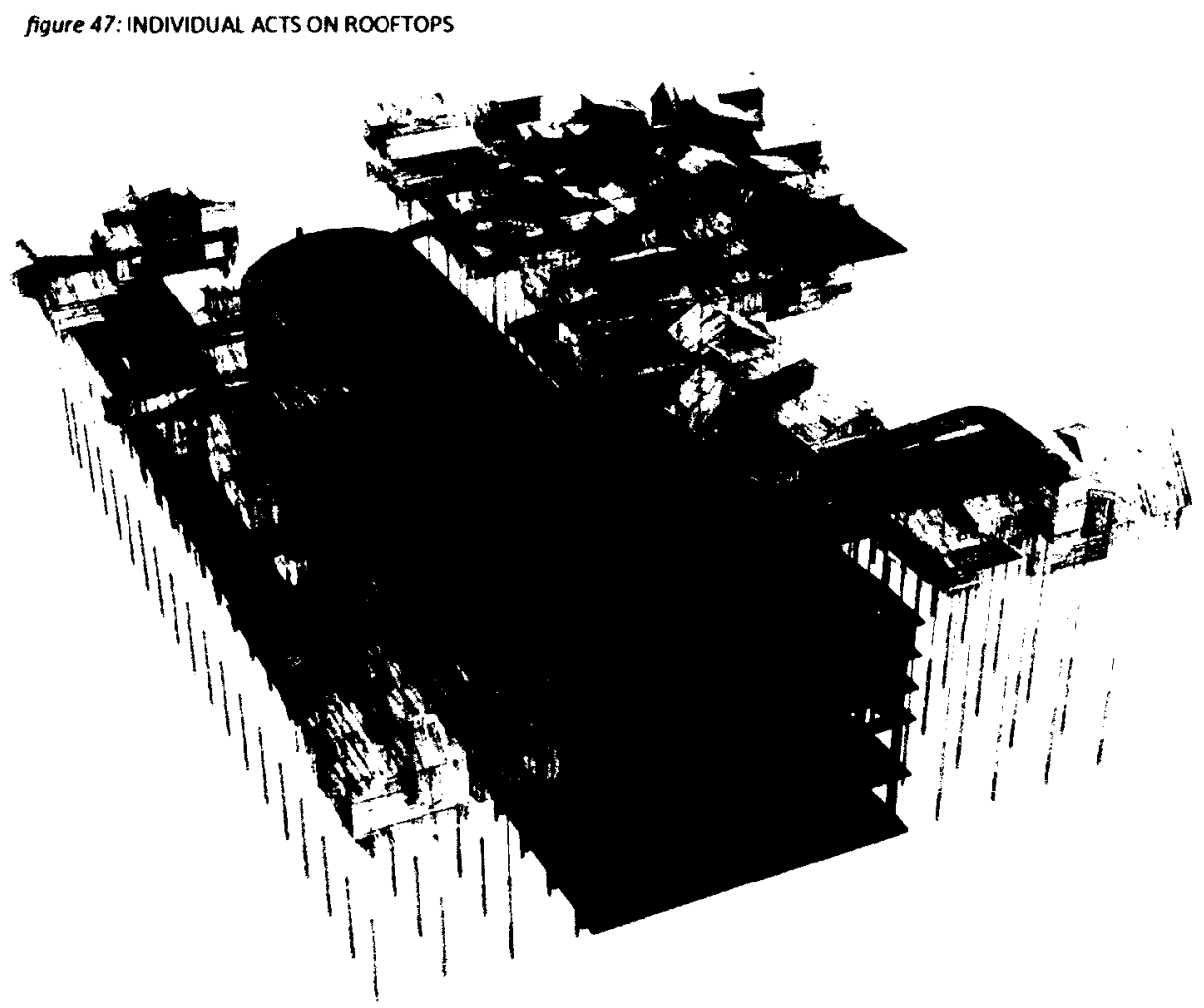

NOMOUAL ACTS MADE POSSIBLE B THE SERYICANG PROVDED IN THE

The main functional program of the parking garage is the extension of the activities of the streets nearby; there are a variety of shops, restaurants, housing and nightclubs in the area. The whole space in the parking structure is serviced by the secondary Glu-lam structure so that temporary or permanent interventions can be built. The parking garage is a structure that will allow its program to be created organically. The floors of the main hall were removed so that the activity on all the levels can be transparent, thus witnessed. It can be assumed that no homes will be built within the structure, due to the lack of sunlight. The rooftops framed by the wooden structure will allow this to happen, as space is provided in open air; yet it is not to say that these areas 
are restricted for housing. The mechanical system that services them will expand as more structures are built can be provided locally by products from companies such as Lennox. Combined, the furnaces and air conditioners can be less than two cubic meters. As more structures are built on the wooden frames, new spatial possibilities emerge that could inspire an observer to act on, such as with the Vasari Corridor on the shops of Ponte Vecchio. As mentioned before, the street is the lifeline of the city. It is where we can find inspiration and access the places we want to go to. The street literally connects us to each other; from personal space, to public space, back to personal space. The journey from and to personal spaces is what is important and what gives rise to surprises; it can make us peer through the lives of others. This structure thus redefines the street, where it leads, and what may be possible from it if given free reign.

\footnotetext{
"Under the seeming disorder of the old city, wherever the old city is working successfully, is a marvelous order for maintaining the safety of the streets and the freedom of the city. It is a complex order. Its essence is intricacy of sidewalk use, bringing with it a constant succession of eyes. This order is all composed of movement and change, and although it is life, not art, we may fancifully call it the art form of the city and liken it to the dance - not to a simple-minded precision dance with everyone kicking up at the same time, twirling in unison and bowing off en masse, but to an intricate ballet in which the individual dancers and ensembles all have distinctive parts which miraculously reinforce each other and compose an orderly whole. The ballet of the good city sidewalk never repeats itself from place to place, and in any once place is always replete with new improvisations." - Jane Jacobs, The Death and Life of Great American Cities
} 
INDIVIDUAL ACT

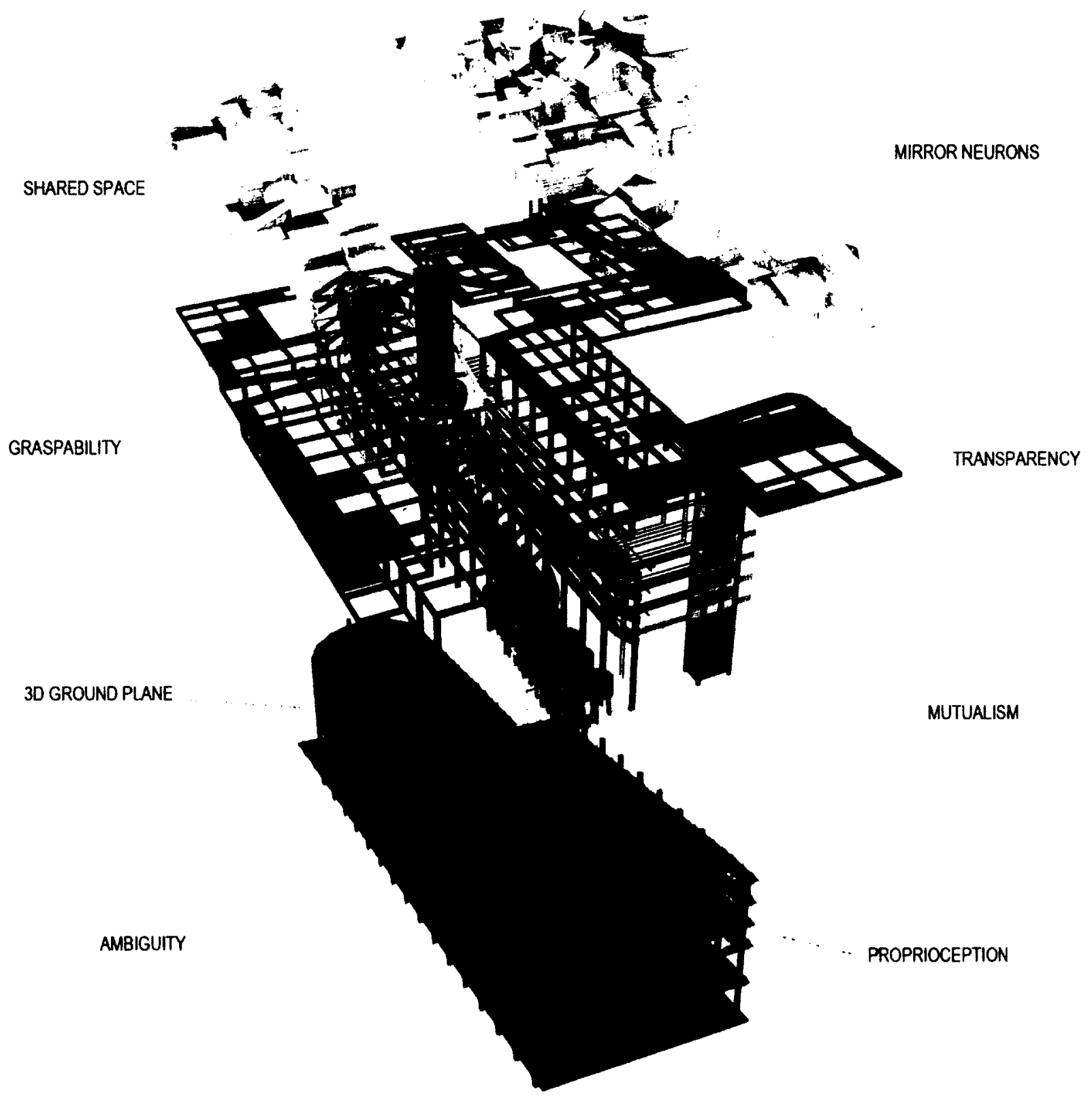

foure 48: EXPLODED BIRD'S EYE VIEW

EXTENSION OF THE STREET 
There are many contemporary architectural critics that claim the city feels alien, emotionless and devoid of tectonic logic. Each building stands on their own, as activities occur inside; activities screened by uniform facades; activities that are essentially cut out from the rest of the world. If mirror neurons puts a person in the point of view of the other, making one feel as the other feels, both in emotion and action, then the modern city is disconnecting itself from its inhabitants.

But the problem actually runs deeper. Neuroscience demonstrates that the city could also disconnect people from themselves. The very phenomenon of perception is to reach in the memory banks of the brain and use it to compare the observed object or scene with an older one stored in the brain. The more memory associations one has about an environment or object, the more that person knows about them, but not only that; these memory associations are imbued with meaning, or a function. One will form a judgement with objects in a scene thus finding some form of association that will attach itself to the unique, newly perceived object in a scene. When this fails to happen, it is because the object in respect to its environment is too coincidental. The 
example given by Ramachandran is of a tree placed exactly between two mountains. This cognitive dissonance creates unease, since the understanding of the object follows its awareness. Artists partake in a similar act of transgression, but its purpose is different; they make us pause our preconceived notions in everyday life and question them. Marcel Duchamp's Fountain is an example of this, for if an inverted urinal was placed as functioning fountain, the object would have a much stronger memory association. In this case, the object becomes ambiguous.

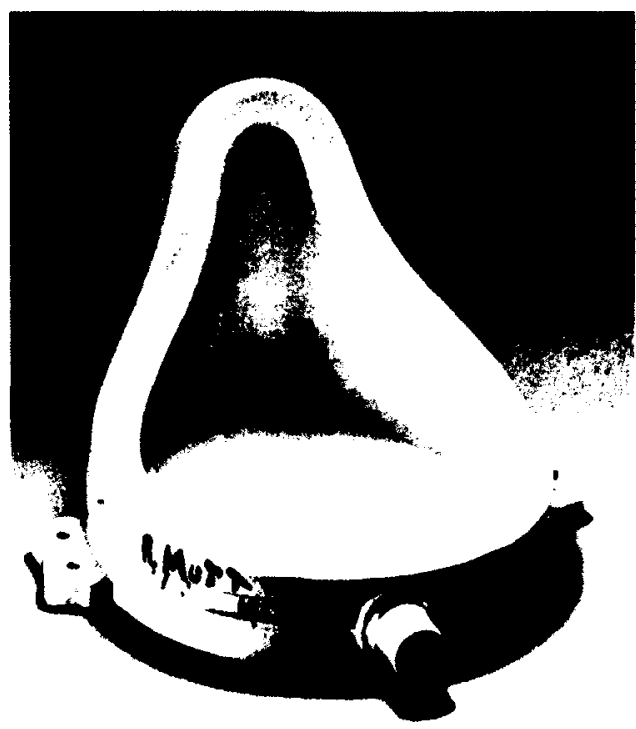

figure 49: THE FOUNTAIN BY MARCEL DUCHAMP, HAS A PERCENED DOUBLE FUNCTION, MAKING IT AMBIGUOUS

The original function of the object was a urinal, as it was designed to do so and is how every man would use it. This implies that every that objects are tied to behavioural tendencies: Ramachandran claims that they are the work of canonical neurons. When someone looks at a branch they imagine, for example, grasping it with their hands, understand how to hold it and potentially use it for their particular use, whether it's use if to climb the tree it is attached to (children do this all the time), or removing it to use for firewood. 
Back to Duchamp: The urinal is flipped and acts as a fountain. The normative associations with urinals are in conflict with its new use, but its distinction with a building is that both functions of the object are eventually perceived. Spatially, this occurs as well. The multiple pediments on Palladio's Redentore present themselves as a mixture of different buildings; as well as the surprise factor with the inhabitable Lantern on Brunelleschi's dome at Santa Maria del Fiore in Florence.

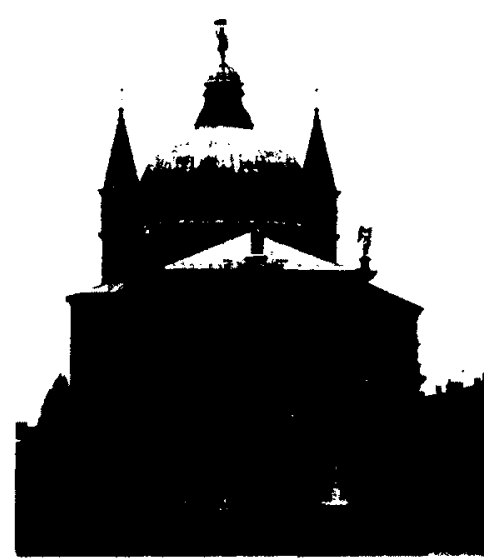

figure 50: ANDREA PALLADIO'S IL. REDENTORE

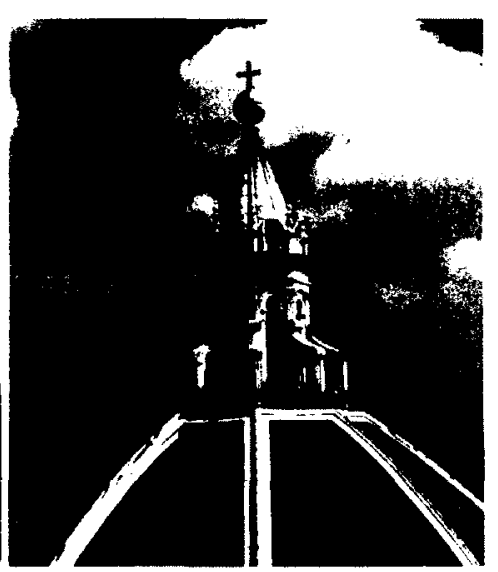

BRUNELLESCHI'S LANTERN AT THE TOP OF SANTA MARIA DEL FIORE'S DOME IN FLORENCE

This is to say that a variety of buildings are pleasing, in a variety of scales, with multiple uses that are perceived as such. This makes them inviting, as stated before, when the brain understands the perception a set of spatial qualities or the function of a particular space, it makes no distinction with being present in that space. Nevertheless, someone undoubtedly know that they are not in that space, but they want to validate the experience by being present in it, which satisfies one of the most ancient emotions: that of seeking.

It can be surmised that a double-function does not have to be predetermined by the architect who designed it. The notion of the poché, introduced by Colin Rowe and Fred Koetter, suggests that any set of 
boundaries can be implementable space. The poché is defined as a field of spatial events which hold both non-predetermined and predetermined spaces which are ever-present: every time something gets constructed, there are unused residual spaces that can vary dimensionally; they can be on rooftops, surfaces, and on sidewalks. These spaces are given meaning by the individual. These attributes are diverse among people, perception of a nonpredetermined space create multiple meanings and functions. Yet first and foremost, these spaces need to be accessible in order for them to be perceived in the first place. Thus buildings should be constructed as explorable environments, and not just with an interior-exterior dichotomy.

This gives rise to emergent architectures since they are not presupposed by a hierarchical structure. No one person or organization determines what these spaces are, but in the modern city they are forbidden to be acted on. There is a presupposition that buildings are built to be complete, while in reality this is never the case because of the creative and emergent nature of the mind. There is always a left-over space that can be imbued with meaning by an observer.

This model is followed in natural law. As explained before, ten different species of ants' wren can inhabit and feed on the ants in single tree. They work mutually to achieve the same goals by occupying different strata of that tree. It is important to state that this does not occur linearly in two dimensional spaces, but it is rather a 3 dimensional phenomenon. Ponte Vecchio followed this model because it was largely non-predetermined and thus fuelled by individual acts. When one act occurs, it is followed by a myriad of other acts (fuelled by mirror neurons), such as with the Rooftop communities of Hong Kong. The 
other various parasitic structures mentioned before and the Hong Kong

Rooftop Communities are identical in their inception; they were all individual acts, some collectivized and some not, but nevertheless individual interventions. It is why the notion of a site must be redefined, as the mind does not discriminate where potentials may lie. In order for people to reclaim a connection to the city, they must be allowed to act on it. 


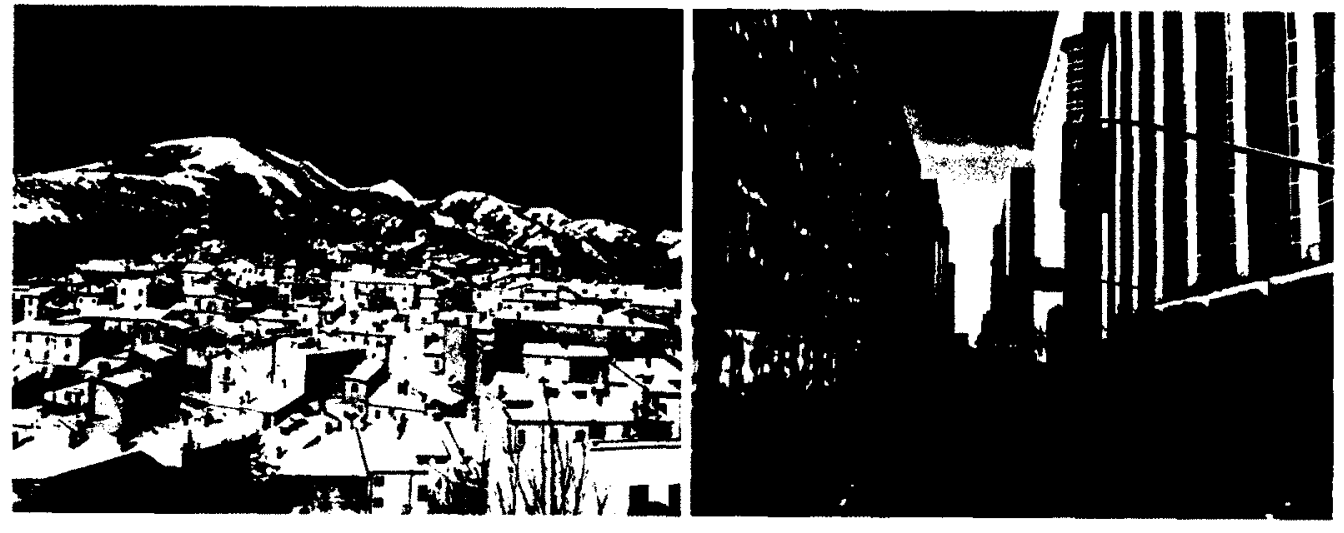


I would like to thank my advisors Marco Frascari, Roger Connah Sheryl Boyle for their invaluable advice, as well as my girffriend Alexandra Chrostek who has been there for me in stressful times. A special thanks to Douglas Cardinal, Anthony Di Virgilio and Kon Shin for their motivation and technical support. 


\section{BIBLIOGRAPHY}

1. Phillips, Rhys. "Avoiding Extinction: Architecture, Place and Politics." OAA/RAIC, 2003. Web. wuw.gvsa.on.ca

2. Barshack, Lion. "The Constituent Power of Architecture." (2010). Print.

3. Koolhaas, Rem, and Bruce Mau. S MLXL: OMA. S.I: S.n., 1993. Print.

4. Pallasmaa, Juhani. The Eyes of the Skin: Architecture and the Senses. Chichester: WileyAcademy, 2005. Print.

5. Harvey, David. The Conditions of Postmodemity, Blackwell (Cambridge), 1992

6. Proshansky, Harold M. Architecture for Human Behaviour - Environmental Psychology and the Design professions. 1970

7. Lynch, Kevin. The Image of the City. Cambridge [Mass.: Technology, 1960. Print.

8. Mallgrave, Harry Francis. The Architect's Brain: Neuroscience, Creativity, and Architecture. Chichester, West Sussex, U.K.: Wiley-Blackwell, 2010. Print.

9. Eberhard, John P. Architecture and the Brain: a New Knowledge Base from Neuroscience. Atlanta, GA: Greenway Communications, 2007. Print.

10. Ramachandran, V. S. The Tell-Tale Brain: A Neuroscientist's Quest For What Makes Us Human New York: W.W. Norton, 2011. Print.

11. Metzinger, Thomas. "Psyche." Précis: Being No One 11.5 (2005): Print.

12. Johansson, Gunnar, Gunnar Jansson, and Claes Von Hofsten. "Event Perception." Annual Review of Psychology 63rd ser. 31.27 (1980): 320-57. Print.

13. Metzinger, Thomas. "Phenomenal Transparency and Cognitive Self-reference. "Phenomenology and the Cognitive Sciences 2.4 (2003): 353-93. Print.

14. Rowe, Colin, and Robert Slutsky. "Transparency: Literal and Phenomenal." Perspecta 8 (1963): 45-54. Print

15. Richard Goodwin, Sydney Based Artist Architect. Web. 09 Jan. 2012. <http://www.richardgoodwin.com/s.

16. Holl, Steven, Juhani Pallasmaa, and Gómez Alberto Pérez. Questions of Perception: Phenomenology of Architecture. San Francisco, CA: William Stout. 2006. Print

17. Rowe, Colin, and Fred Koetter. Collage City. Cambridge, MA: MIT, 1978. Print

18. Woods, Lebbeus. Anarchitecture: Architecture Is a Political Act. London: Academy Editions, 1992. Print

19. "YouTube - Lebbeus Woods. Experimental Space and Architecture. 2006 1/8." YouTube Broadcast Yourself. Web. 06 July 2011. http://www. youtube.com/watch?v=HA1QJGkNz4E

20. "Parasite I Define Parasite at Dictionary.com." Dictionary.com / Free Online Dictionary for English Definitions. Web. 04 Mar. 2011. <http:/dictionary.reference.com/browse/parasite>.

21. "Arcosanti : Media : Interview." Arcosanti : Home. Web. 06 Nov. 2011.

22. Planet Earth. Perf. David Attenborough. BBC, 2006. DVD

23. MAD Architects Hutong Bubble 32." A+U Magazine 478 (2010): Print

24. From Hutong to "New-Tong"'". Beijing This Month.

25. "Siheyuan." Wikipedia, the Free Encyclopedia. Web. 06 Nov. 2011. <http:/len.wikipedia.org/wiki/Siheyuan>

26. "Biodiversity Urban Sprawl Threatens Biodiversity ." eNotes - Literature Study Guides, Lesson Plans, and More. . N.p., n.d. Web. 21 Apr. 2011. <http.//www.enotes.com/biodiversityarticle/urban-sprawl-threatens-biodiversity>.

27. Bloomer, Kent C., and Charles Willard Moore. Body, Memory, and Architecture. New Haven: Yale UP, 1977. Print.

28. Goy, Richard J. Florence: the City and Its Architecture. London: Phaidon, 2006. Print

29. Locke, Tim, and Anne Locke. Bridges of the World: an Illustrated History. Basingstoke: AA, 2008. Print.

30. Neumann, Stan, Richard Cowan, and Frederic Compain. "Maison De Verre Documentary." Mvgroup.com - Market Developing, marketing Resources and Information. This Website /s for Sale! Web. 19 Nov. 2011. http://www.mvgroup.com

31. Venturi, Robert. Complexity and Contradiction in Architecture. New York: Museum of Modern Art, 1977. Print.

32. Ouroussoff, Nicolai. "Maison De Verre - Robert Rubin - New York Times." The New York Times Breaking News, World News \& Multimedia. 19 Nov. 2011. Web. 19 Nov. 2011 <http://www.nytimes.com/2007/08/26/arts/design/26ouro.html?pagewanted=all>

33. Terborgh, John. Diversity and the Tropical Rain Forest. New York: Scientific American Library. 1992. Print.

34. Yoneda, Yuka. "BIG Unveils Gigantic Cube Building with a Rooftop Park Ted Cube Building by BIG Architects - Inhabitat - Green Design Will Save the World." Green Design Will save the World [ Inhabitat. 8 Oct. 2010. Web. 03 Mar. 2011. <http://inhabitat.com/big-unveils-gigantic-cubebuilding-with-a-rooftop-park/ted-cube-building/?extend $=1>$.

35. Orangemenace. "Parasite Architecture." AMNP. Apr.-May 2007. Web. 04 Mar. 2011.

36. Lynch, Kevin. A Theory of Good City Form. Cambridge, MA: MIT, 1981. Print

37. Wu, Rufina, Stefan Canham, and Ernest Chui. Portraits from Above: Hong Kong's Informal Rooftop Communities. [Berlin]: Peperoni, 2008. Print. 


\section{IMAGE INDEX}

Uncanny Dynamism (Frontispeice) - http://sundayist.wordpress.com/2011/04/07/imperial-boy-teikokushounent

Figure i: Ovindoli Panoramic - http://uww.abruzzocitta.it/aziendecomuni/ovindoli/immagini.html

Figure ii: Albert Street - maps.google.ca

Figure 1: Mies Seagram Building - http://macvayapah.blogspot.com/2010_04_01_archive.htm!

Figure 2: Thomas Mayne Phare Tower - http://arpafil.blogspot.com/2009/08/thom-mayne.html

Figure 3: Albert Street, Ottawa, Canada -

Figure 4: Ovindoli, Italy - http://maps.google.ca

Figure 5: C.D. Howe Building - http://maps.google.ca

Figure 6: Alto Palermo Plaza - http://en.wikipedia.org/wiki/File:Alto_Palermo_\%28Avenida_Santa_Fe\%29.jpg

Figure 7: Ssamziegil Mall - http://picasaweb.google.com/h/photo/1X68g10LJsUV1JLTOsSWMA

Figure 8: Tree Between Two Mountains - The Tell Tale Brain - V.S. Ramachandran

Figure 9: Splatter Scene - The Tell Tale Brain - V.S. Ramachandran

Figure 10: Tree - http://www.angeloaktree.org/home/292150647_Angel_Oak_15.jpg

Figure 11: Palazzo Medici - http://en.wikipedia.org/wiki/File:Palazzo_medici_riccardi,_bugnato_01.JPG

Figure 12: Mental Association - http://www.rightmove.co.uk/developer/branch/Nottingham-CommunityHousing- Association/Melbourne-92156.html

Figure 13: Tower Typology - http://www.skyscrapercity.com/showthread.php?t=817894\&page=45

Figure 14: L'Arlesienne - http://art.wallpapers-free.co.uk/art/picasso/1930s/portrait-of-lee-miller-at-the-

arlesienne/

Figure 15: Bauhaus

http://mww.exmsft.com/ davidco/Travel/Berlin/pages/5\%20a1\%20berlin $\% 20$ bauhaus $\% 20$ perspect $\% 20054$ -

1 edited.htm

Figure 16: St.Mary's Church - http://uww.djcarchitect.com/

Figure 17: Gaudi Hanging Chain Study for Sagrada Familia - http://travellinglloyds.blogspot.com/2011/03/wevisit-some-gaudi-buildings.html

Figure 18:

- Figure ground diagram - http://www.tripplannermag.com/wpcontent/uploads/2010/07/b1.-noli-plan.jpg

- Free-Form - http://industrialdesigntopicc.wikispaces.com/2.+Individual+Research++ Becky+

Figure 19:

- Egyptian Plover feeding off a crocodile - http://www.wolaver.org/animals/crocodileplover.htm

- Red- Billed Oxpecker feeding off an ox - http://tripwow.tripadvisor.com/slideshowphoto/red-billed-oxpecker-mutualism-n1-hluhluwe-southafrica.html?sid=12399232\&fid=upload 12915143373-tpfil02aw-30526

Figure 20: Hutong Bubble Plan and Section - http://5osa.tistory.com/entry/MAD-Beijing-Hutong-Bubble Figure 21: Hutong Bubble Connecting Spaces - http://5osa.tistory.com/entry/MAD-Beijing-Hutong-Bubble Figure 22: Hutong Bubble Rooftop view - http://5osa.tistory.com/entry/MAD-Beijing-Hutong-Bubble Figure 23: Hutong Bubble Street View - http://5osa.tistory.com/entry/MAD-Beijing-Hutong-Bubble Figure 24: Mirror Neurons - http://www. federica.unina. it/lettere-e-filosofia/filosofia-della-mente/neuronispecchio-mente/

Figure 25: Ponte Vecchio Site Plan - http://maps.google.ca

Figure 26: Ponte Vecchio - http://giobaltraveltorusim. blogspot.com/2011/07/florence-duomo-and-pontevecchio-italia.html

Figure 27: Maison inserted like a Jenga piece - http://paris.untappedcities.com/2010/07/28/the-maison-deverre-house-of-glass/

Figure 28:

o Bookcase - http://makearchitecture.wordpress.com/people-2/jd-sassaman/12-finalproject-proposal/

o Sliding Bookcase - http://makearchitecture.wordpress.com/people-2/jd-sassaman/12final-project-proposal/

- Screened Stairway - http://paris.untappedcities.com/2010/07/28/the-maison-de-verrehouse-of-glass/

- Access Stainway - http://autobiographicalhouses.wordpress.com/tag/maison-de-verre/

Figure 29: Maison de Verre Interior View - http://www.erzed.nl/enparis.html

Figure 30:

- Robie House Porch - http://www.galinsky.com/buildings/robie/

- Robie House Entrance http://kubuildingtech.org/sarcweb/Assemblages00/CaseFinals/kristenrowellrobiehouse/ROBIE.html

Figure 31: Robie House Snapshot - http://aytch.mnsu.edu/Chicago/

Figure 32: Big TEK Cube X-Ray Views - http://buildipedia.com/in-studio/featured-architecture/public-spacethat-doesn-t-suck-bjarke-ingels-group-s-big-tek-center?print=1\&tmpl=component

Figure 33: 
Figure 34:

Figure 35:

Big TEK Cube Street view (Rendering) - http://www.tours. am/en/outgoing/news/157

- Big TEK Cube View through the void (rendering) -

http://www.tours.am/en/outgoing/news/157

$\begin{array}{ll}\circ & \text { Las Palmas Parasite up close - http://architecture.myninjaplease.com/?p=944 } \\ \circ & \text { Las Palmas Parasite Interior View - http://architecture.myninjaplease.com/?p=944 }\end{array}$

- Las Palmas Parasite being craned into place http://www.flickr.com/photos/dezeruimte/6147977297/lightbox/

- Las Palmas Parasite in the urban landscape http://architecture. myninjaplease.com/?p=944

- Las Palmas Parasite Sections - http://architecture myninjaplease.com/?p=944

Figure 36:

- Rooftop village 1 - http://uww.lumenvisum.org/eng/

- Rooftop Village Panoramic -

http://sustainablecitiescollective.com/urbantickurbantick/15368/hong-kongs-rooftopvillages

- Rooftop Village 2 - http://sustainablecitiescollective.com/urbantickurbantick/15368/hongkongs-rooftop-villages

- Interior View of a Unit

hitp://sustainablecitiescollective.com/urbantickurbantick/15368/hong-kongs-rooftopvillages

Figure 37: Byward Markey Aerial View - maps.google.ca

Figure 38: Byward Markey with Actvity - http://www.ottawafestivals.ca/tag/byward-market/

Figure 39: Longitudinal Section of Existing Parking Garage - Author's Rendering

Figure 40: Parking Garage on George Street (a) and York Street (b) - maps google.ca

Figure 41: Concrete Rails Replaced by Glass - Author's Rendering

Figure 42: Cut through Concrete Slabs and Structure - Author's Rendering

Figure 43: Supporting Glulam Structure - Author's Rendering

Figure 44: Steel Posts in Existing Stores - Author's Rendering

Figure 45: Wood Conduits Providing Services - Author's Rendering

Figure 46: Ramps Leading to Rooftops - Author's Rendering

Figure 47: Individual Acts on Rooftops - Author's Rendering

Figure 48: Exploded Bird's Eye View - Author's Rendering

Figure 49: Marcel Duchamp the Fountain - http://imagerepository.net/tag/duchamp-fountain

Figure 50:

- Andrea Palladio's Redentore - $h$ ttp://guttae.blogspot.com/2009/11/andrea-palladio-ilredentore-venice.html

- Santa Maria del Fiore - http:/www.britannica.com/bps/media-view/6337/1/0/0

Figure 51:

o ? - http://www.abruzzocitta.it/aziendecomuni/ovindoli/immagini.html

o ? - maps.google.ca 